\title{
Algal extracellular release in river-floodplain dissolved organic matter: response of extracellular enzymatic activity during a post-flood period
}

\author{
Anna Sieczko*, Maria Maschek and Peter Peduzzi \\ Department of Limnology and Bio-Oceanography, Inland Water Microbial and Viral Ecology, University of Vienna, Vienna, Austria
}

\section{Edited by:}

Télesphore Sime-Ngando, Centre

National de la Recherche

Scientifique, France

\section{Reviewed by:}

Ingrid Obernosterer, Observatoire Océanologique de Banyuls-sur-Mer, France

Eric Fouilland, Centre National de la Recherche Scientifique, France France Van Wambeke, Centre National de la Recherche

Scientifique, France

\section{${ }^{*}$ Correspondence:}

Anna Sieczko, Department of Limnology and Bio-Oceanography, Inland Water Microbial and Viral Ecology, University of Vienna, Althanstrasse 14, 1090 Vienna, Austria

e-mail:anna.sieczko@univie.ac.at
River-floodplain systems are susceptible to rapid hydrological events. Changing hydrological connectivity of the floodplain generates a broad range of conditions, from lentic to lotic. This creates a mixture of allochthonously and autochthonously derived dissolved organic matter (DOM). Autochthonous DOM, including photosynthetic extracellular release (PER), is an important source supporting bacterial secondary production (BSP). Nonetheless, no details are available regarding microbial extracellular enzymatic activity (EEA) as a response to PER under variable hydrological settings in river-floodplain systems. To investigate the relationship between bacterial and phytoplankton components, we therefore used EEA as a tool to track the microbial response to non-chromophoric, but reactive and ecologically important DOM. The study was conducted in three floodplain subsystems with distinct hydrological regimes (Danube Floodplain National Park, Austria). The focus was on the post-flood period. Enhanced $\%$ PER (up to $48 \%$ of primary production) in a hydrologically isolated subsystem was strongly correlated with $\beta$-glucosidase, which was related to BSP. This shows that-in disconnected floodplain backwaters with high terrestrial input-BSP can also be driven by autochthonous carbon sources (PER). In a semi-isolated section, in the presence of fresh labile material from primary producers, enhanced activity of phenol oxidase was observed. In frequently flooded river-floodplain systems, BSP was mainly driven by enzymatic degradation of particulate primary production. Our research demonstrates that EEA measurements are an excellent tool to describe the coupling between bacteria and phytoplankton, which cannot be deciphered when focusing solely on chromophoric DOM.

Keywords: extracellular enzymatic activity, photosynthetic extracellular release, autochthonous DOM, nonchromophoric DOM, river-floodplain

\section{INTRODUCTION}

In river-floodplain systems seasonal floods or low water episodes create a range of lotic to lentic conditions in the backwaters. Depending on the duration and frequency of spates and on the distance of a side arm from the main channel, different types of side backwaters can be distinguished. These range from frequently connected to fragmented and very rarely flooded parts to side-arms that are completely disconnected from the main channel. Rapid hydrological events introduce substantial loads of terrestrial dissolved organic matter (DOM) into the floodplain (Hein et al., 2003). Moreover, disconnected and stable hydrological situations, observed after a flood, enhance phytoplankton productivity (Hein et al., 1999). This creates a complex DOM pool with a mixture of allochthonously and autochthonously derived material, potentially available for bacterial utilization.

Autochthonous autotrophic production is an important carbon source also for secondary production in rivers (Thorp and Delong, 2002; Bunn et al., 2003). Nonetheless, DOM generated in situ often is insufficient to exclusively support aquatic food webs (Kritzberg et al., 2004). Particularly in aquatic systems where primary production is low compared with the terrestrial load of DOC (Kritzberg et al., 2005), allochthonous DOC can become essential for bacterial secondary production (BSP) (Jansson et al., 2000). BSP may be much higher when faced with pulse resource addition compared to the same quantity of DOC supplied continuously over a longer time period (Lennon and Cottingham, 2008). This points to the importance of seasonal disturbance events (such as floods) for BSP.

Even if most of carbon needed for bacterial growth may be supplied from other than autochthonous sources (Fouilland and Mostajir, 2010), the autochthonous material is preferentially utilized prior to terrestrial DOM. In pelagic zones, an important source of autochthonous carbon is photosynthetic extracellular release of phytoplankton (PER). The link between PER and bacterial heterotrophic metabolism has been studied in freshwater and marine systems. In floodplain studies, however, this is rarely measured routinely. The rate and quality of the exudated material depends on the phytoplankton species, cell size (López-Sandoval et al., 2013) and on the type of aquatic ecosystem (Fogg, 1983). 
Nutrients (Meon and Kirchman, 2001; Wyatt et al., 2014), light (Hulatt et al., 2009), UV radiation (Pausz and Herndl, 1999) and other factors can also significantly impact the percentage, composition and microbial utilization of PER (Sarmento and Gasol, 2012; Landa et al., 2013). Related phytoplankton species may produce similar suits of DOM, which has implications for shaping bacterial communities (Becker et al., 2014). However, the composition of PER may depend on the growth phase of phytoplankton (Barofsky et al., 2009). In general, most primary production exudates are high-quality substrates, comprised mainly of monomeric sugars, carboxylic acids and amino acids (Bertilsson and Jones, 2003), which can be directly assimilated by bacteria, stimulating the growth and abundance of microbial communities (Norrman et al., 1995). Numerous studies have revealed the importance of PER for bacterial metabolism and the direct utilization of PER by bacteria (Cole, 1982; Chrzanowski and Hubbard, 1989; Baines and Pace, 1991). Nonetheless, other studies could not demonstrate direct coupling between BSP and PER (Teira et al., 2003; López-Sandoval et al., 2010). Thus, beside monomeric compounds, phytoplankton exudates may be composed also of high molecular weight material, mostly polymeric sugars (Myklestad, 1995; Giroldo and Vieira, 2005), which are not directly available for bacteria. In such cases, an enzymemediated step is necessary to assimilate these polymeric exudates. The optical properties of PER provide information on PER composition (Stedmon and Markager, 2005; Romera-Castillo et al., 2011). Such investigations, however, do not cover the broad range of non-chromophoric compounds that are also exudated (Rochelle-Newall and Fisher, 2002). Measurements of extracellular enzymatic activity (EEA) is an alternative approach that enables tracking the microbial response to non-chromophoric, but quickly cycling DOM. The activity of extracellular enzymes enables detecting shifts in the microbial response to varying resources (Wagner et al., 2014), especially those that are relatively quickly exploited by the bacterial community. Production of extracellular enzymes by bacteria can be regulated by the DOM supply (Chróst, 1991) and it is directly linked to mechanisms of DOM processing (Sinsabaugh and Foreman, 2001). Hence EEA likely is regulated by the composition of phytoplankton exudates (Chróst and Siuda, 2006).

Model enzymes used to study bacterial degradation of carbohydrates and proteins are $\beta$-glucosidase and leu-aminopeptidase (Cunha et al., 2010), but the activity of other enzymes has also been measured frequently (Chróst and Siuda, 2002; Sinsabaugh, 2010). Although some studies report the extracellular enzymatic response to phytoplankton exudates in the water column (Obernosterer and Herndl, 1995; Fajon et al., 1999) and sediments (Goto et al., 2001), this topic remains understudied. Especially under variable hydrological settings in river-floodplain systems this process has been neglected.

Our study was designed to compare water column processes in three different floodplain sections located in a river-floodplain system of the Danube. The focus was on the post-flood period. We investigated relationships between natural phytoplankton productivity and microbial EEA in these distinct subsystems. The main goals of the study were:
- to characterize potential environmental differences between subsystems located in relatively close vicinity in the same floodplain area,

- to investigate how extracellular enzymes respond to primary production, emphasizing the effect of phytoplankton extracellular release in temporarily compared to permanently disconnected water bodies,

- to elucidate the importance of autochthonous, phytoplanktonderived DOM for microbial uptake in an environment typically dominated by allochthonous DOM,

- to elucidate whether the main DOM sources for bacterial growth are different in hydrological individual and diverse subsystems of a floodplain after a flood.

\section{MATERIALS AND METHODS STUDY SITE}

The study was conducted in the area of the "Danube Floodplain National Park" (DFNP) downstream of Vienna, Austria. Some parts of this area are severely impacted by human activity (river regulation), whereas others were restored about 15 years ago (Schiemer et al., 1999). Water samples were collected after a 30year flood from backwaters located in three different subsystems of the DFNP (Figure 1). These subsystems, although close to one another, exhibit distinct hydrological regimes, with different types of surface connectivity with the main Danube channel. Subsystem I (hereafter termed: I) is located in a semi-natural and restored part of the river-floodplain, where two side arms (A and B) were chosen (Figure 1). Although A and B are situated in different sections of the DFNP, both have very similar characteristics. They have been restored by lowering the riverbank, which results in frequent changes of lentic to lotic and flowing conditions (220 (A) and 180 (B) days per year). In subsystem II (hereafter: II) two temporarily disconnected backwaters (C) and (D) were selected (Figure 1). Section C and D are located in a semi-separated area of the floodplain, which is protected from direct flow-through by a levee and additional weirs. Here, a surface connection of backwaters with the main channel is established only rarely (average 18 days per year), during higher water level of the Danube $(>1.30 \mathrm{~m}$ above mean water). Both backwaters are open water bodies, where DOM derives from external (fallen leaves, rare river water import) as well as from internal sources (phytoplankton, macrophytes). Subsystem III (hereafter: III) in former times was an integral part of the "active" floodplain area, but due to a major regulation of the river in the nineteenth century (embankment and additional weirs), subsystem III has been permanently separated from the main channel. Therefore, it is never flushed even during exceptional floods. Hence, surface connection with the Danube is never established; the only connection with the Danube is through infiltration from groundwater. Subsystem III is situated in a highly shaded area (average light intensity at midday: $195 \mu \mathrm{mol}$ photons PAR $\mathrm{m}^{-2} \mathrm{~s}^{-1}$ ) where the dominating DOM input is probably of allochthonous origin (leaves, debris).

Water samples from all stations were always collected between 10 and 12 a.m. with rinsed polyethylene bottles (101, single sample) and transported to the laboratory within $3 \mathrm{~h}$ in dark boxes at in situ temperature. Surface water sampling was performed 


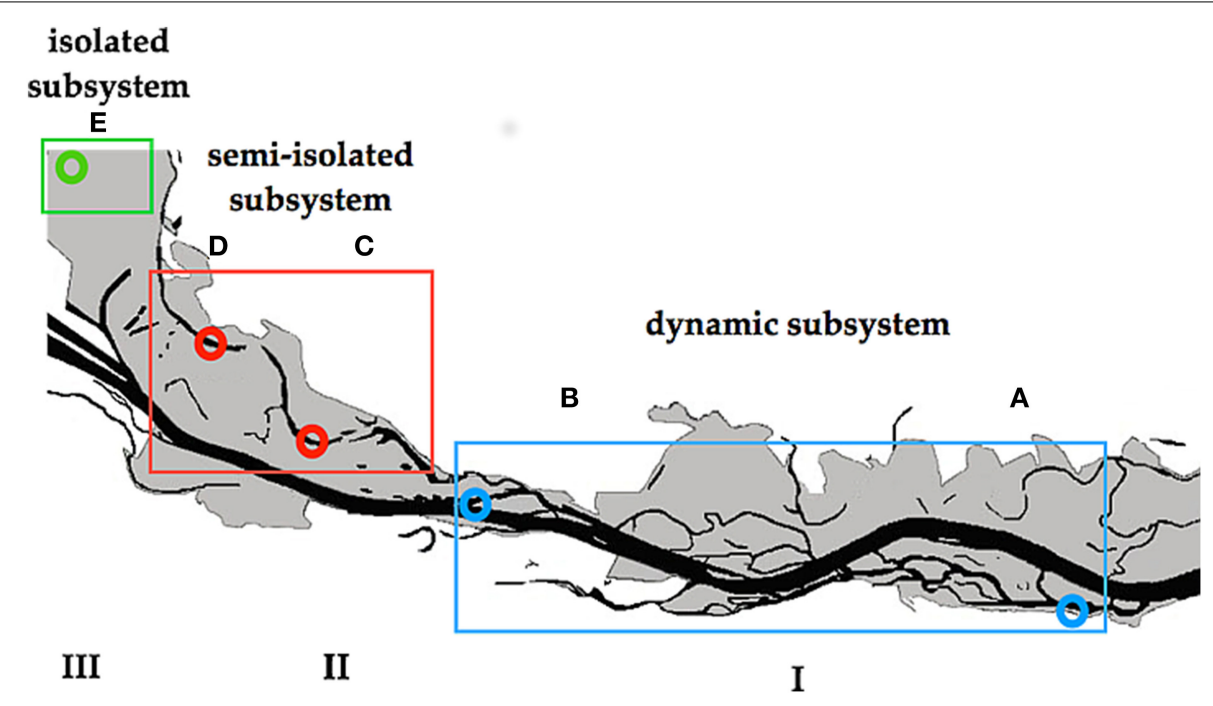

FIGURE 1 | Danube River and its floodplains downstream of Vienna. Letters indicate the sampling sites. I-III indicate different subsystems.

between July and October 2009, which covered the post-flood period. In subsystems II and III the sampling included a 2-weekslonger period than in I. Because both locations in subsystem I still experienced flooding conditions in early July, we did not include these samples into our post-flood analyses. Water samples from subsystem I were collected on 5 dates, whereas in II and III, samples were taken on 9 dates. The intensity of sampling was more frequent at the onset of the post-flood phase (every few days) and decreased toward the end of the investigation period (every month). In subsystem I the first sample was taken 7 days after flood while in subsystem II, 3 days after the flooding.

\section{ANALYSES OF ABIOTIC PARAMETERS}

Water level, temperature, oxygen saturation (WTW, Oxi 315i) and vertical profiles of light intensity ( $\mu \mathrm{mol}$ photons PAR $\mathrm{m}^{-2}$ $\mathrm{s}^{-1}$, every $10 \mathrm{~cm}$, LICOR sensor) were measured in situ at each location. The key nutrients determined included: three nitrogen compounds-nitrate, ammonia, dissolved organic nitrogen (DON)—and soluble reactive phosphorus (SRP). These analyses were completed within $24 \mathrm{~h}$ using the German standard methods: nitrate: DIN 38405-29, ammonia: DIN 38406-5, SRP: DIN EN ISO 6678, soluble KjeldahL-N: DIN 38406-5. DON was assessed by subtracting ammonia from soluble KjeldahL-N (Peduzzi et al., 2008) and the ratio DOC/DON was determined. The ratio of dissolved inorganic nitrogen [(nitrate+ammonia) (DIN)] and SRP was calculated as DIN/SRP.

\section{PRIMARY AND SECONDARY PRODUCERS \\ Phytoplankton productivity and biomass}

To make our measurements comparable, the samples for primary production were taken at the same time of day during all sampling events right below the water surface $(10-20 \mathrm{~cm})$. Particulate primary production (pPP) and net photosynthetic extracellular release (PER) of phytoplankton were determined using a ${ }^{14} \mathrm{C}$ method, originally proposed by Steemann-Nielsen (1974), modified according to Preiner et al. (2008). We measured the rate of carbon fixed in particulate material (cells; pPP), while PER was assessed to estimate dissolved organic carbon released by phytoplankton into the surrounding water. Total primary production (PPt) was calculated as the sum of pPP and PER. Assessing PPt was needed to calculate the relative fractions. For each station, 8 bottles with a defined volume $(\sim 117 \mathrm{ml})$ were incubated in a water basin at in situ temperature for 3.5-4 h after adding sodium bicarbonate $\left(\mathrm{NaH}^{14} \mathrm{CO}_{3}\right)^{14} \mathrm{C}(20 \mu \mathrm{Ci} / \mathrm{ml})$. This time period was selected according to Myklestad (2000) and Preiner et al. (2008) assuming that, on one hand, it was not too short to obtain measurable results. On the other hand, avoiding that the bacterial community has not passed its latent period and not reached maximum uptake rates. With this it was attempted to minimize a bias due to potentially remaining bacterial uptake. Bottles were exposed in a light gradient covering the environmental conditions $\left(10-560 \mu \mathrm{mol}\right.$ Photons $\left.\mathrm{m}^{-2} \mathrm{~s}^{-1}\right)$. The sample water was permanently mixed by placing the bottles on a rolling table. Two additional bottles were kept in dark to determine the unspecific adsorption of ${ }^{14} \mathrm{C}$. After the incubation, filtration $(0.45 \mu \mathrm{m}$; Millipore HAWP) separated the particulate from the dissolved fraction (Wetzel and Linkens, 1990) using low vacuum pressure $(<50 \mathrm{mBa})$. The filtrate from each sample $(5 \mathrm{ml})$, including dark-incubated samples, was collected. The filters were placed in scintillation vials with $0.5 \mathrm{ml} 0.5 \mathrm{~N} \mathrm{HCl}$ to remove the inorganic ${ }^{14} \mathrm{C}$ (Peterson, 1980). The filtrate was decontaminated by acidifying the samples to $\mathrm{pH} 4$ and bubbling with air for $15 \mathrm{~min}$ (Peterson, 1980; Parsons et al., 1984). Filters were dissolved with ethyl acetate to minimize self-adsorption (Peterson, 1980) and scintillation cocktail was added. After $24 \mathrm{~h}$ radioactivity of each sample was measured in a scintillation counter (Parsons et al., 1984) to determine disintegrations per minute (DPMs). DPMs of dark-incubated samples were subtracted to calculate pPP and PER. For the characterization of the light climate, the light attenuation coefficient was determined from vertical light profiles and light curves (P/I curves) were created. Primary production $[\mu \mathrm{g} \mathrm{C}$ $\mathrm{l}^{-1} \mathrm{~h}^{-1}$ ] was calculated according to Jassby and Platt (1976) based 
on surface radiation, the attenuation coefficient and the depth where the samples were taken (Riedler and Schagerl, 1998). The analytical variability was always $<10 \%$. The rate of carbon fixed in particulate organic matter (cells; pPP) was compared to the rate of dissolved organic carbon released extracellularly by phytoplankton (PER). The relative extracellular release was defined as percentage of total primary productivity $(\mathrm{PPt}): \% \mathrm{PER}=\mathrm{PER} \times$ 100/(PP+PER). Additionally, for a biomass estimate, the concentrations of chlorophyll $a(\mathrm{chl} a)$ were determined using standard methodology (Lorenzen, 1967); the method is described in more details by Schagerl et al. (1996).

\section{Bacterial secondary production}

Bacterial secondary production (BSP) was assessed based on the method of $\left[{ }^{3} \mathrm{H}\right]$ thymidine $(20 \mu \mathrm{l}, 20 \mathrm{nM}$ final concentration) incorporation into DNA (Fuhrman and Azam, 1982). Three replicate samples and two additional formaldehyde-killed (2\% final concentration) samples $(5 \mathrm{ml})$, which served as controls, were incubated in dark at ambient temperature for $0.45-1.5 \mathrm{~h}$. After the incubation, samples and controls were filtered $(0.45 \mu \mathrm{m}$; Millipore HAWP). Filters were collected in scintillation vials and dissolved in ethyl acetate. Afterwards scintillation cocktail was added and samples were placed into the scintillation counter. The analytical variability was always $<10 \%$. BSP $\left[\mu \mathrm{g} \mathrm{C}^{-1} \mathrm{~h}^{-1}\right.$ ] was calculated using an average Danube-specific conversion factor of $3.2 \times 10^{18}$ cells produced per mol of incorporated thymidine (Berger et al., 1995). The ratio of BSP:PPt was calculated, based on hourly rates as an instantaneous $\mathrm{BSP} / \mathrm{PPt}$ ratio, the ratio right at the day time of sampling. This ratio was used to establish the relative share of primary production used by BSP, hence to characterize a potential coupling between the bacterial and phytoplankton compartments (Ducklow and Carlson, 1992).

\section{Bacterial abundance}

Sample water (1-2 ml) was fixed with formaldehyde (2\% final concentration) and stained with 4.6-diamidino-2-phenylindoledihydrochloride (DAPI) $\left(10 \mu \mathrm{g} \mathrm{ml}^{-1}\right)$. Bacterial abundance (BA) was determined by epifluorescence microscopy (Nikon E 800) in 20-30 randomly chosen fields according to Porter and Feig (1980).

\section{DOM characterization}

Water samples were filtered through pre-combusted $\left(500^{\circ} \mathrm{C}\right)$ GF/F filters $(0.7 \mu \mathrm{m}$, pore size $)$ within $3 \mathrm{~h}$ of collection. Samples for DOC concentration [ $\mathrm{mg} \mathrm{l}^{-1}$ ] were acidified to $\mathrm{pH} 3$ and analyzed by high-temperature combustion using a Shimadzu TOC 5000 analyzer (Benner and Strom, 1993). We applied optical DOM indices to obtain information about DOM quality in each subsystem. Absorbance at wavelengths of 364, 254, and $250 \mathrm{~nm}$ was measured in a $5-\mathrm{cm}$ quartz cuvette with a spectrophotometer (Hitachi U-2000). Carbon-specific UV absorbance (SUVA 254 ) [1 $\mathrm{mg}^{-1} \mathrm{~m}^{-1}$ ] was calculated as the ratio of absorbance at $254 \mathrm{~nm}$ to the DOC concentration. SUVA 254 is reported to be positively correlated with DOC aromaticity (Weishaar et al., 2003). SUVA 254 has also been used as an indicator of terrestrial sources of DOM (Jaffé et al., 2008). Additionally, the ratio of absorbance measured at $250 \mathrm{~nm}$ to absorbance at $364 \mathrm{~nm}$ (E2:E3 ratio), first proposed by De Haan and Boer (1987), was calculated. The E2:E3 ratio was determined to track changes in the relative size of DOM molecules. E2:E3 is inversely related to average DOM molecular weight, hence higher E2:E3 ratios, indicate lower molecular weight of DOM. The E2:E3 ratio has been shown to be a good indicator to track alterations in molecular weight of DOM during and after rapid hydrological changes (Åren et al., 2008). Furthermore, to distinguish DOM originating from microbial sources (including algal-derived) from terrestrially derived DOM, the fluorescence index (FI) (McKnight et al., 2001; Sieczko and Peduzzi, 2014) was determined with a Shimadzu spectrofluorophotometer RF-5301 PC. FI is the ratio of the emission intensity at $450-500 \mathrm{~nm}$ under excitation at $370 \mathrm{~nm}$; FI end-values of $\sim 1.3$ indicate allochthonously produced DOM, whereas $\sim 2.0$ implies autochthonously derived material.

\section{Extracellular enzymatic activity (EEA)}

EEA was measured to infer available organic matter sources as suggested by Boschker and Cappenberg (1998) for natural systems. Hence we used EEA as a tool to obtain information about availability of non-chromophoric but reactive and quickly cycling DOM (Sieczko and Peduzzi, 2014). Part of the rapidly metabolized DOM (including phytoplankton-derived DOM) is non-chromophoric, but it also includes bioavailable polysaccharides and proteins. Hence, this part of the DOM pool cannot be tracked with standard optical methods. Therefore, serving as a proxy, this ecologically important DOM was investigated by EEA measurements.

Fluorogenic substrate analogs were used to assess potential hydrolysis rates of $\alpha-, \beta$ - glucosidic and peptide bonds. To estimate the activity of $\alpha-$ (EEAa) and $\beta$ - (EEAb) glucosidase, 4- methylumbelliferyl (MUF)- $\alpha$-D-glucoside and 4 -MUF- $\beta$-D-glucoside were used, respectively. To measure the activity of leucine aminopeptidase (EEAleu), L-leucine 7-amido4-methylcoumarin was used. For measuring the extracellular enzymatic activity, triplicates of $3 \mathrm{ml}$ of sample water with $15 \mu$ l fluorescently- labeled substrates (final, substrate saturating concentration: $2.5 \mu \mathrm{M}$ ) were incubated in the dark at in situ temperature. Fluorescence of the replicates was measured immediately after adding the substrate $\left(\mathrm{t}_{0}\right)$ and after $45-90 \mathrm{~min}\left(\mathrm{t}_{1}\right)$ at an excitation wavelength of $360 \mathrm{~nm}$ and an emission wavelength of $444 \mathrm{~nm}$ (Hoppe, 1983) with a spectrofluorophotometer (Shimadzu RF-5301 PC). Substrate degradation was calculated from the increase in fluorescence over time as nmol substrate hydrolyzed per liter per hour (Hoppe, 1993).

Phenol oxidase activity $(\mathrm{PhOx})$ was measured spectrophotometrically following the method outlined by Pind et al. (1994). Incubations were completed by mixing $2 \mathrm{ml}$ of unfiltered sample water with $2 \mathrm{ml}$ of L-3,4-Dihydroxyphenylalanine (DOPA) stock solution ( $5 \mathrm{mM}$ DOPA in $2.5 \mathrm{mM} \mathrm{NaHCO} 3$ buffer, $\mathrm{pH}$ 8.3). Thus, the substrate saturating, final concentration for our samples was $2.5 \mathrm{mM}$ DOPA. The absorbance was measured at $460 \mathrm{~nm}$ in a spectrophotometer (Hitachi U-2000) immediately after addition of DOPA $\left(\mathrm{t}_{0}\right)$ and after incubation in dark $\left(\mathrm{t}_{1}\right)$ at in situ temperature for $180-220 \mathrm{~min}$. Results were calculated using Beer's Law and the molar absorbancy coefficient for the DOPA product 3-dihydroindole-5.6-quinone-2-carboxylate 
(diqc) $\left(3.7 \times 10^{4}\right.$; Mason, 1948). Phenol oxidase activity was expressed in nmol of product (diqc) produced per liter per hour.

\section{Statistical analyses}

For the statistical tests we used R 2.15.0 and SPSS 17.0 for Windows. Most of the data were normally distributed and fulfilled the conditions to apply parametric tests ( $T$-test and One-Way ANOVA), unless stated otherwise. In such cases, non-parametric tests such as Wilcox- and KruskaL-Wallis tests were applied. Only the data used for correlations and linear regressions were logtransformed and the residuals were tested for normal distribution and homogeneity of variances.

\section{RESULTS}

\section{SELECTED ENVIRONMENTAL AND DOM CHARACTERISTICS}

Most of the abiotic parameters of subsystem III were clearly distinct from parameters at subsystems I and II. Different nutrient conditions occurred: in subsystems I and II, SRP was significantly lower compared to III, $(p<0.001, n=42)$, whereas the lowest DIN was noted in II. Hence the DIN/SRP-ratio diverged from the Redfield ratio and was significantly higher in I and II than in III $(p<0.001, n=42)$ (Table 1). Average oxygen saturation $\left[\mathrm{O}_{2} \%\right]$ was significantly different between all subsystems $(p<0.001, n=42)$, with the highest values at I (Table 1). The organic nutrient ratio (DOC/DON) ranged from 13:1 to 62:1 (Table 1), with significantly higher values at II and III compared to I $(p<0.001, n=42)$. The DOC quantity and the qualitative proxies for DOM in the permanently disconnected subsystem (III) were distinct from I and II, with significantly higher DOC $(p<0.001), \mathrm{SUVA}_{254}(p<0.01)$, higher E2:E3 ratio $(p<0.05)$ and lower FI $(p<0.001)$ in III (Table 1). The DOC quantity in I and II decreased by $50 \%$ during the investigation period, while in III it increased by $30 \%$, (data not shown). Also SUVA 254 in I and II dropped (43, 57\%, respectively) while E2:E3 increased by 20 and $35 \%$, respectively, toward the end of the sampling season (early October) compared with the values measured at the onset of the post-flood period. DOM quantity and quality in subsystems I and II did not significantly differ from each other. In III SUVA 254 and E2:E3 were relatively constant; the only considerable increase was noted in the middle of the sampling season (data not shown).

\section{PHYTOPLANKTON BIOMASS, PRIMARY PRODUCTION AND PHOTOSYNTHETIC EXTRACELLULAR RELEASE}

Phytoplankton biomass and productivity varied distinctly along the connectivity gradient from dynamic to isolated sites. After the flood, in mid-August, the pPP increased markedly and reached the highest values in station $\mathrm{A}\left(263.4 \mu \mathrm{g} \mathrm{C}^{-1} \mathrm{~h}^{-1}\right)$ and $\mathrm{B}$ $\left(213.1 \mu \mathrm{g} \mathrm{Cl}^{-1} \mathrm{~h}^{-1}\right.$ ) (Supplementary Figures $\left.1 \mathrm{~A}, \mathrm{~B}\right)$. In subsystem II, the pPP also increased after the flood, the highest pPP rate $181.9 \mu \mathrm{g} \mathrm{C}^{-1} \mathrm{~h}^{-1}$ occurring at the end of the sampling period (Supplementary Figures 1C,D). In subsystem III, pPP was much lower and fluctuated considerably, peaking in September $(41.9 \mu \mathrm{g}$ $\mathrm{C}^{-1} \mathrm{~h}^{-1}$ ) (Supplementary Figure 1E).

On average, chl $a$ and pPP rates were highest in I; pPP rates in III were even 7 times lower than in I (Figures 2A,B). Chl $a$ and $\mathrm{pPP}$ were correlated significantly only in the semi-isolated subsystem (II) $(r=0.82, p<0.001, n=14)$.

Phytoplankton cells excreted variable amounts of photosynthesis products (PER) into the water. PER in I remained in the range of 1.54-7.46 $\mathrm{g} \mathrm{C}^{-1} \mathrm{~h}^{-1}$ (Supplementary Figures 2A,B). The highest PER coincided well with an increase in $\mathrm{pPP}$ rates in both locations in I. In II and III, PER fluctuated considerably (0.68-11.3 $\mu \mathrm{g} \mathrm{C}^{-1} \mathrm{~h}^{-1}$ and 2.02-17.0 $\mu \mathrm{g} \mathrm{C}^{-1} \mathrm{~h}^{-1}$, respectively) with the highest rates in the end of the sampling period (Supplementary Figures 2C-E). Overall, subsystem III was characterized by generally higher rates of PER, but due to high variability, no significant differences in PER between the subsystems were noted (Figure 3A). Also the percentage of PER (\% PER) was highly variable in each subsystem throughout the sampling season. Nonetheless, average \% PER increased significantly at locations with lower connectivity with the main river channel (Figure 3B). The share of PER on total primary production $(\mathrm{PPt})$ in I ranged from 0.9 to $3.4 \%$, in II from 0.9 to $12.3 \%$ whereas in the isolated subsystem (III), the values were between 12.2 and $47.9 \%$ of PPt.

\section{EXTRACELLULAR ENZYMATIC ACTIVITY IN DIFFERENT SUBSYSTEMS OF THE FLOODPLAIN}

The EEA rates showed different patterns in the three subsystems (Supplementary Figure 2). In both stations of subsystem I, all the measured enzymes strongly coincided with each other (Supplementary Figures 2A,B); hence, hydrolases

Table 1 | Min-max values of: nutrients (DIN, SRP, DIN/SRP ratio), oxygen saturation and DOM quantity (DOC) and quality (DOC/DON, SUVA 254 , FI ratio, E2:E3 ratio) in subsystems I-III; average in brackets.

\begin{tabular}{|c|c|c|c|c|c|c|c|c|c|}
\hline Subsystem & $\begin{array}{c}\text { DIN } \\
{\left[\mu \mathrm{g} \mathrm{I}^{-1}\right]}\end{array}$ & $\begin{array}{c}\text { SRP } \\
{\left[\mu \mathrm{g} \mathrm{I}^{-1}\right]}\end{array}$ & $\begin{array}{c}\text { Ratio } \\
\text { DIN/SRP }[g / g]\end{array}$ & $\mathrm{O}_{2}[\%]$ & $\begin{array}{c}\text { DOC } \\
{\left[\mathrm{mg} \mathrm{I}^{-1}\right]}\end{array}$ & $\begin{array}{c}\text { Ratio } \\
\text { DOC/DON }\end{array}$ & $\begin{array}{c}\text { SUVA } \\
{\left[\mathrm{l} \mathrm{mg}^{-1} \mathbf{m}^{-2}\right]}\end{array}$ & $\mathbf{F I}$ & $\begin{array}{l}\text { E2:E3 } \\
\text { ratio }\end{array}$ \\
\hline I & $\begin{array}{c}107.5-1478.9 \\
(743.1)\end{array}$ & $\begin{array}{c}0.88-25.7 \\
(8.68)\end{array}$ & $\begin{array}{c}37.3-485.1 \\
(181.7)\end{array}$ & $\begin{array}{c}74-147 \\
(104)\end{array}$ & $\begin{array}{c}1.30-2.61 \\
(1.88)\end{array}$ & $\begin{array}{c}12.9-22.9 \\
(17.1)\end{array}$ & $\begin{array}{c}3.53-7.53 \\
(5.79)\end{array}$ & $\begin{array}{c}1.52-1.68 \\
(1.62)\end{array}$ & $\begin{array}{c}4.66-6.79 \\
(5.82)\end{array}$ \\
\hline II & $\begin{array}{c}86.9-349.7 \\
(181.4)\end{array}$ & $\begin{array}{c}0.78-3.24 \\
(1.44)\end{array}$ & $\begin{array}{c}60.7-332.5 \\
(132.8)\end{array}$ & $\begin{array}{c}50-100 \\
(75)\end{array}$ & $\begin{array}{c}1.98-4.37 \\
(2.63)\end{array}$ & $\begin{array}{c}13.3-41.5 \\
(23.2)\end{array}$ & $\begin{array}{c}3.58-8.38 \\
(6.34)\end{array}$ & $\begin{array}{c}1.40-1.66 \\
(1.58)\end{array}$ & $\begin{array}{c}4.34-6.69 \\
(5.34)\end{array}$ \\
\hline
\end{tabular}

For abbreviations see text. 

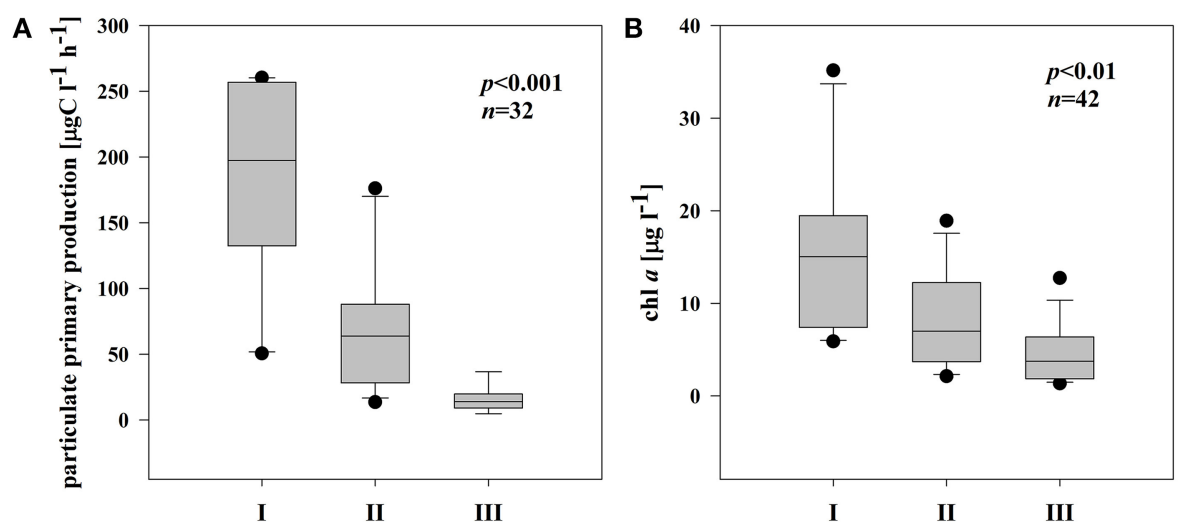

FIGURE 2 | Boxplots illustrating average chl a (A) and pPP rates (B) in three different subsystems (I-III) during the sampling period. The boundaries of the box plot indicate the 25th and 75th percentiles, points indicate outliers, the solid line in the box marks the median. Statistical differences are indicated on the top of each panel (for applied statistical tests see Section Materials and Methods).

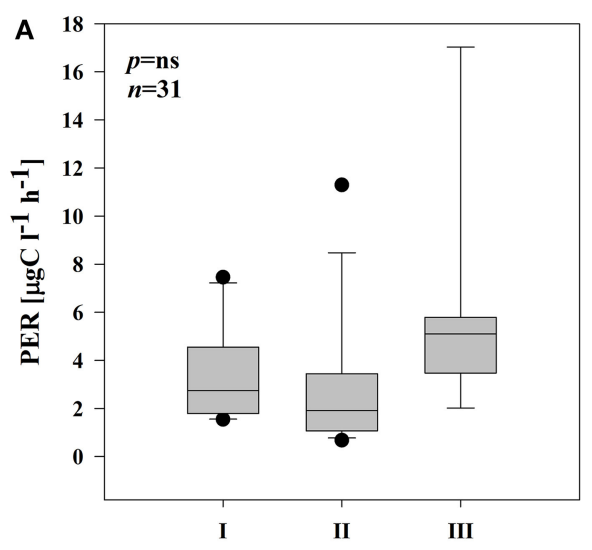

FIGURE 3 | Boxplots illustrating average PER rate (A) and \% of PER release in PPt (B) in three different subsystems (I-III) during the sampling period. The boundaries of the box plot indicate the 25th and 75th

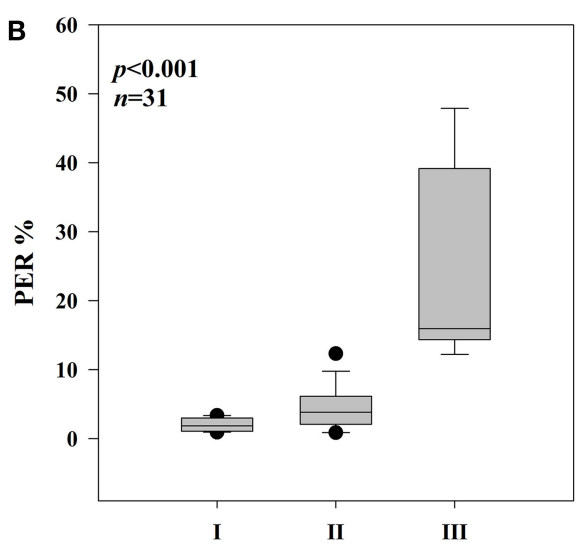

percentiles, points indicate outliers, the solid line in the box marks the median. Statistical differences are indicated on the top of each panel (for applied statistical tests see Section Materials and Methods). and oxidase were strongly and positively correlated (Table $2 \mathrm{~A}$ ). In subsystem II, EEA was more variable, but, the hydrolytic enzymes coincided quite well during the investigated post-flood period (Supplementary Figures 2C,D); correlations between hydrolytic enzymes (glucosidases with leu-aminopeptidase) were still observed (Table 2B). The hydrolase activity peaked in subsystem III, while PhOx showed the lowest rates here toward the end of the sampling period (Supplementary Material Figure 2E). Extracellular enzymes in III were more decoupled, but similarly to other subsystems the activities of the two glucosidases (EEAa and EEAb) coincided well throughout the investigated post-flood period (Table 2C). Activity of glucosidases (Figures 4A,B) and $\mathrm{PhOx}$ (Figure 4C) were on average highest in III, whereas EEAleu was highest in the dynamic subsystem (I) (Figure 4D). Among the hydrolytic enzymes, EEAleu displayed the highest activity, which was 3-4 orders of magnitude higher than EEAa and EEAb activity. In line with the gradient of connectivity between I, II, and III, decoupling of the different enzymatic activities occurred (Table 2).

\section{BACTERIAL ABUNDANCE AND PRODUCTION}

Total bacterial numbers (BA) in all the subsystems ranged from

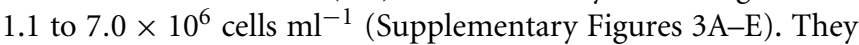
were on average higher in III but not significantly different between the three subsystems (Figure 5A).

BSP ranged from $0.24-3.91 \mu \mathrm{g} \mathrm{C}^{-1} \mathrm{~h}^{-1}$ with occasionally highest rates in III (Supplementary Figures 3A-E). Due to high variability, however there were no significant differences between subsystems (Figure 5B). BSP followed a similar pattern as BA in subsystems I and II (Supplementary Figures 3A-D), hence BSP was significantly correlated with BA in I $(r=0.82, p<0.01$, $n=10)$ and in II $(r=0.56, p<0.05, n=18)$.

\section{MICROBIAL RESPONSE ON DOM CHARACTERISTICS}

BSP and BA were not related to DOM quality (based on optical properties) in any of the subsystems. No direct enzymatic response to any of the qualitative proxies was observed in subsystem I and III. In subsystem II, however, the synthesis of EEAa and EEAb was apparently related with $\mathrm{SUVA}_{254}$ (Figures 6A,B). 
Table 2 | Correlation coefficients between extracellular enzymatic activity (EEAa, EEAb, EEAleu, phOx) in subsystem I (A), subsystem II (B), and subsystem III (C).

\begin{tabular}{lcccc}
\hline & EEAa & EEAb & EEAleu & phOx \\
\hline I (A) & & & & \\
EEAa & - & $0.98^{* * *}$ & $0.86^{* *}$ & $0.73^{*}$ \\
EEAb & & - & $0.90^{* * *}$ & $0.70^{*}$ \\
EEAleu & & - & $0.76^{*}$ \\
phOx & & & & - \\
II (B) & & $0.98^{* * *}$ & $0.50^{*}$ & $\mathrm{~ns}$ \\
EEAa & - & - & $0.54^{*}$ & $\mathrm{~ns}$ \\
EEAb & & & - & $\mathrm{ns}$ \\
EEAleu & & & & - \\
phOx & & & $\mathrm{ns}$ & $\mathrm{ns}$ \\
III (C) & & & $\mathrm{ns}$ & $-0.65^{*}$ \\
EEAa & - & $-74^{*}$ & - & $\mathrm{ns}$ \\
EEAb & & - & & - \\
EEAleu & & & & \\
phOx & & & & \\
\hline
\end{tabular}

${ }^{*} p<0.05,{ }^{* *} p<0.01,{ }^{* * *} p<0.001$. The data were log-transformed.

EEAa and EEAb were also negatively related to the E2:E3 ratio (Figures 6C,D).

\section{RELATIONSHIPS BETWEEN EXTRACELLULAR ENZYMATIC ACTIVITY AND PRIMARY AND SECONDARY PRODUCTION}

Depending on the subsystem, the extracellular enzymes exhibited distinct relationships with phytoplankton and bacterial parameters. In the dynamic subsystem (I), hydrolase activity was strongly promoted by the primary production rate and biomass (pPP and chl a) (Table 3). Beyond a positive relation between PhOx and chl $a(r=0.46, p=0.05, n=14)$ in II, no other direct enzymatic response to chl $a$ occurred in subsystems II and III. There was, however, a clear enzymatic response to phytoplankton extracellular release. The synthesis of $\alpha$-and $\beta$-glucosidase clearly coincided with PER in subsystem I (Supplementary Figures 2A,B); EEAa and EEAb were apparently promoted by PER (Figures $7 \mathrm{~A}, \mathbf{B}$ ). However, in subsystem II, the opposite tendency was noted; the activity of EEAa and EEAb was negatively related to PER (Figures 7C,D). In subsystem III, EEAb corresponded to PER (Supplementary Material Figure 2E), hence it was positively related to PER (Figure 7E).

Since DOM properties, based on our optical assessment of DOM quality, were not related to BSP or BA, the enzymatic approach helped to elucidate which DOM was important for bacterial metabolism in each subsystem. Accordingly, we linked EEA to BSP to investigate which DOM pool was more important for bacterial metabolism in our three different subsystems. Our results imply that degradation of distinct material supported bacterial growth in each subsystem differently. More than one enzyme explained BSP variability; we therefore performed stepwise multiple regression analyses using a combination of EEAleu, EEAa, EEAb, and PhOx as independent variables. This revealed that in each subsystem different enzymes were the most significant predictors for BSP (Table 4). In I, only
EEAleu was directly related to bacterial production. In II, BSP was best described by the activity of EEAleu and PhOx, while in subsystem III, EEAb explained most of the variability in BSP (Table 4).

In I, pPP was directly related to BSP $(r=0.67, p<0.05)$ and BA $(r=0.64, p<0.05)$. Phytoplankton biomass ( $\mathrm{chl} a)$ also positively related to BA in I $(r=0.65, p<0.05)$ and BSP in II $(r=$ $0.49, p<0.05, n=17)$. There was no direct response of bacterial production or abundance to photosynthetic extracellular release (PER) in any of the subsystems.

In subsystem I, where the highest pPP was observed (Figure 3), the BSP:PPt ratio was the lowest; bacterial production there ranged from 0.38 to $3.06 \%$ (average $1.07 \%$ ) of the total primary production. On average the BSP:PPt ratio was more than 2 times higher in III than in II, where it remained in a range of $2.01-17.7 \%(8.65 \%)$ and $0.58-10.6 \%(3.66 \%)$, respectively.

\section{DISCUSSION}

\section{ENZYMATIC ACTIVITY: RESPONSE TO DOM QUALITY}

This study was designed to shed light on the microbial response to various allochthonous and autochthonous DOM sources in different sections of a floodplain. Our results show that DOM in all subsystems was a mixture of allochthonous and autochthonous material. Although no significant differences were noted between subsystem I and II after the flood, this study points to the more autochthonous, less aromatic DOM in subsystem I. However, in subsystem III DOM was clearly more allochthonous, higher molecular weight and more aromatic. This is very likely due to input of local terrestrial material (dense surrounding vegetation), because this subsystem is never connected to the main channel. In other subsystems (I and II) allochthonous material derives also from the main channel during occasional surface connection with the Danube (Sieczko and Peduzzi, 2014). Differences in the DOM composition and availability can be important in determining the functioning of microbial communities (Hoostal and Bouzat, 2008). Our results, however, do not generally support the idea that enzymatic activity is strongly linked to DOC quantity or quality based solely on optical measurements. Even though the quantitative and qualitative parameters of DOM were significantly different between the investigated subsystems, only in subsystem II did we find a significant relation between enzymatic activity and optical properties of DOM.

The positive relation between EEAa, EEAb activity and $\mathrm{SUVA}_{254}$ or molecular size of DOM (Figures 6A-D) implies enhanced expression of glucosidases in the presence of terrestrially derived, higher molecular weight DOM. There is evidence that HMW substances can be even more reactive as long as they are diagenetically younger (Amon and Benner, 1996) compared to diagenetically older LMW residues of former bacterial metabolism (Ogawa et al., 2001). Nonetheless, molecular weight or origin are not the only factors regulating DOM bioavailability. For example, microbial communities are most productive when metabolizing their native DOM sources (Young et al., 2005). This could explain that, in other subsystems, EEA was not related to the molecular size of DOM and that other factors might have been important. 

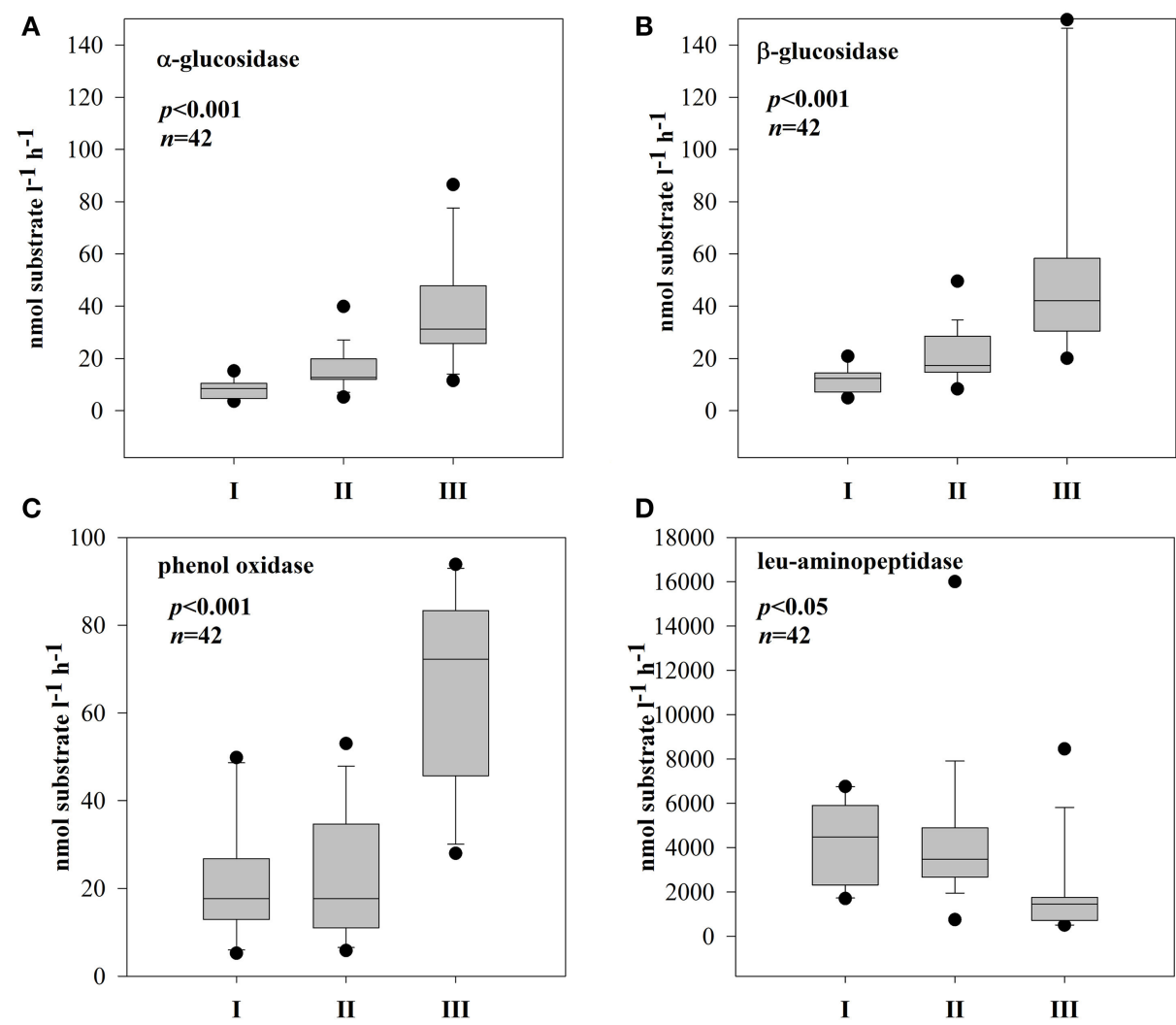

FIGURE 4 | Boxplots of extracellular enzymatic activity of $\alpha$-glucosidase (A), $\beta$-glucosidase (B), phenol oxidase (C), and leu-aminopeptidase (D) in three different subsystems (I-III). The boundaries of the box plot indicate

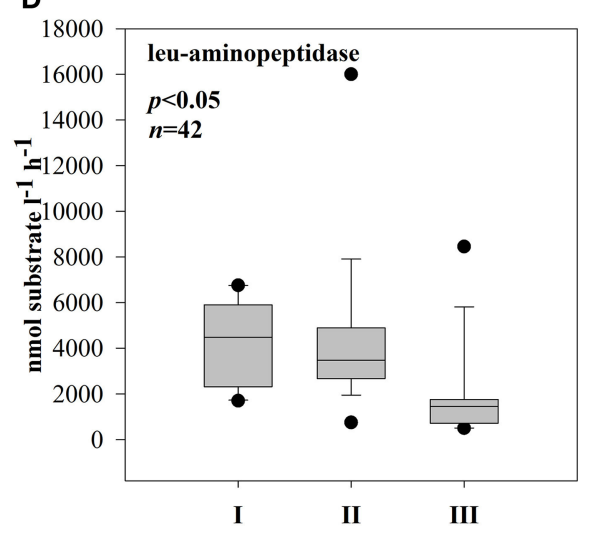

the 25th and 75th percentiles, points indicate outliers, the solid line in the box marks the median. Statistical differences are indicated on the top of each panel (for applied statistical tests see Section Materials and Methods).

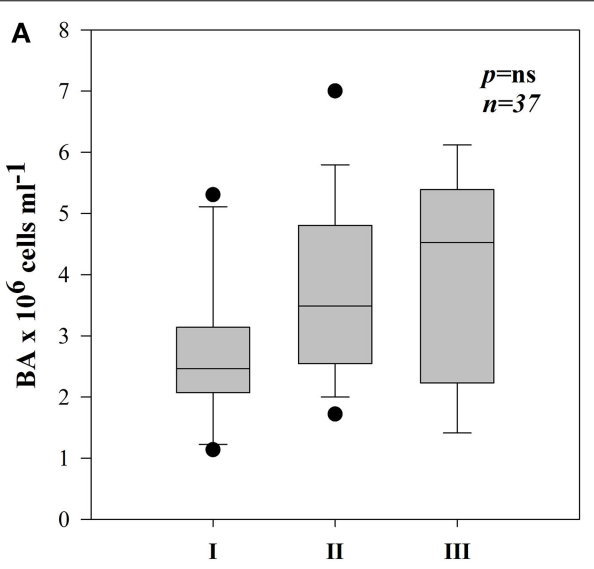

FIGURE 5 | Boxplots of average BA (A) and BSP (B) in three different subsystems (I-III). The boundaries of the box plot indicate the 25th and 75th percentiles, points indicate outliers, the solid line in

\section{RELATIONSHIP BETWEEN PHYTOPLANKTON AND MICROBIAL ENZYME ACTIVITIES}

The mechanisms behind enzyme synthesis are regulated by a number of environmental factors which may induce or suppress production of extracellular enzymes (Sinsabaugh and Follstad

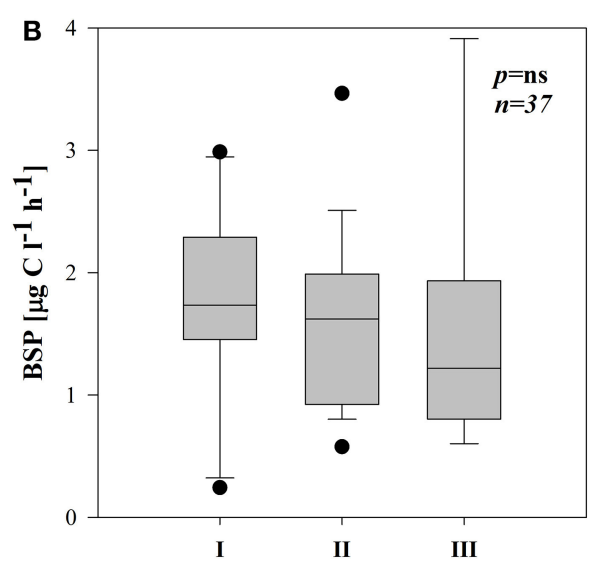

the box marks the median. Statistical differences are indicated on the top of each panel (for applied statistical tests see Materials and Methods).

Shah, 2012; Arnosti et al., 2014). In our study, we attempted to evaluate the importance of autotrophic planktonic production for EEA. Our results show that in subsystem I, primary production (pPP and chl $a$ ) was strongly and positively related to EEAleu (Table 1), which indicates the importance of algal products here. 

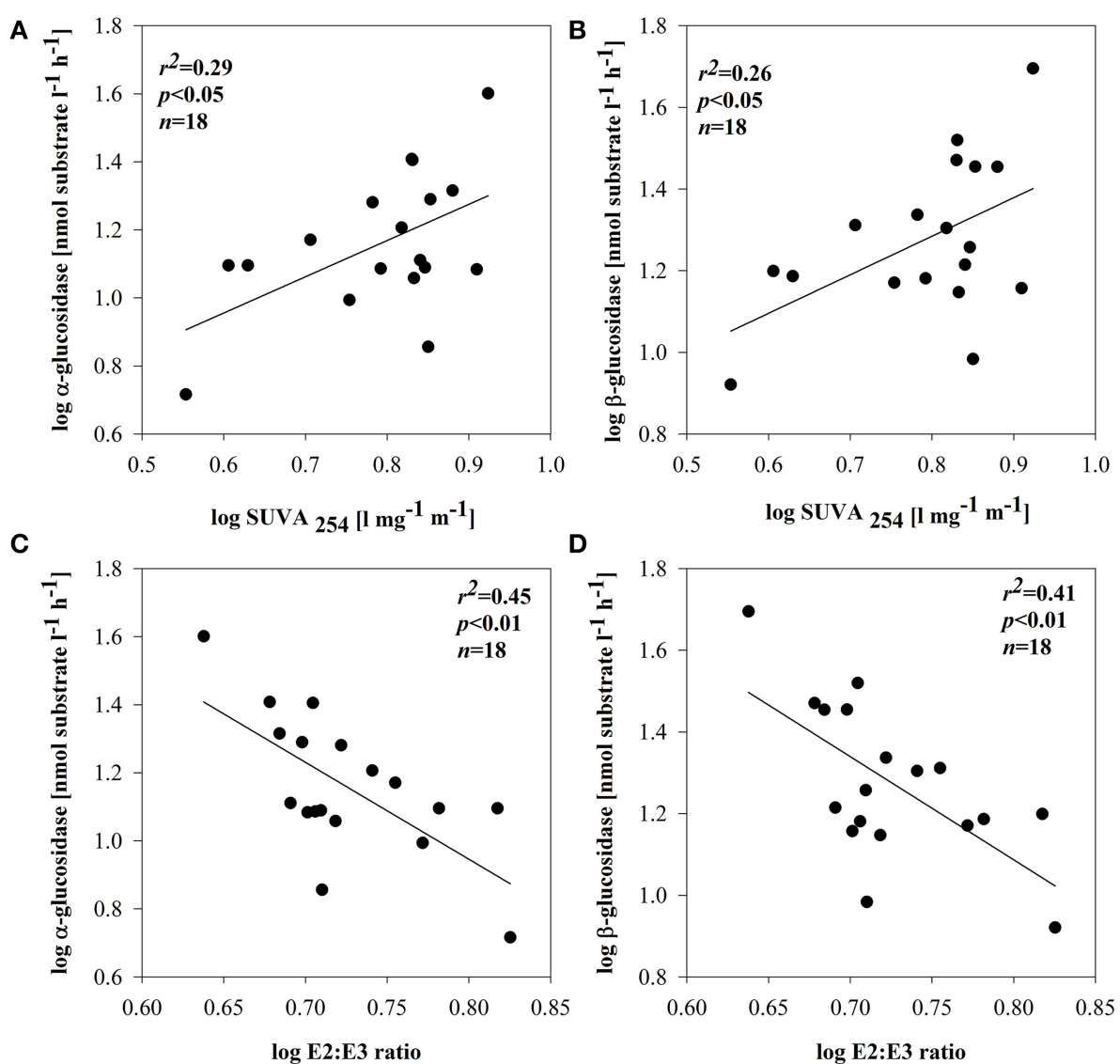

FIGURE 6 | Relationships between SUVA 254 and: $\alpha$-glucosidase (A) or $\beta$-glucosidase (B) and E2:E3 ratio and: $\alpha$-glucosidase (C) or $\beta$-glucosidase (D) in subsystem II. All data were log-transformed.

Table 3 | Correlation coefficients between extracellular enzymatic activity (EEAa, EEAb, EEAleu, PhOx) and phytoplankton parameters (pPP and chl a) in subsystem I.

\begin{tabular}{lcc}
\hline & pPP & chl $\boldsymbol{a}$ \\
\hline EEEa & $0.82^{* *}$ & $0.81^{* *}$ \\
EEAb & $0.85^{* *}$ & $0.87^{* *}$ \\
EEAleu & $0.83^{* *}$ & $0.77^{* *}$ \\
phOx & $\mathrm{ns}$ & $\mathrm{ns}$
\end{tabular}

${ }^{* *} p<0.01$. The data were log-transformed.

Studies in river environments showed that EEAleu was actively produced when autochthonous production of labile organic matter was high (Wilczek et al., 2005). One potential reason for quite high activity levels of EEAleu in our study, compared to the activity of other enzymes, is that aminopeptidases are not very specific in their cleaving (Chróst, 1992) and that they can hydrolyze many different peptides.

In I we also observed strong correlations between all the enzymes, including PhOx (Table 3). This indicates a tight coupling of metabolic pathways (Hoostal and Bouzat, 2008) and mutualism within the microbial community here. Further, in subsystem II, the strong and positive relation between $\mathrm{PhOx}$ and chl a may indicate that input of fresh labile material from primary producers was able to augment synthesis of $\mathrm{PhOx}$.

The phenomenon of enhanced production of extracellular enzymes degrading recalcitrant $\mathrm{OM}$ in the presence of labile OM is called priming effect (PE) (Guenet et al., 2010; Bianchi, 2012) and it has already been proven in laboratory assays (Shimp and Pfaender, 1985) and field studies (Treignier et al., 2006; Rier et al., 2007, 2014). Although our data may imply that in subsystems I and II phytoplankton-derived material possibly could influence the expression enzymes responsible for degrading recalcitrant DOM, more extensive studies on a potential priming effect here would be necessary. However, we suggest that riverfloodplain systems are places where ample opportunities for this phenomenon are created. This calls for further investigations on the existence of a priming effect in hydrologically dynamic river-floodplain systems.

Carbon-rich exudates are often predominant products of phytoplankton growing under an imbalanced DIN/SRP ratio (Penna et al., 1999). Production of bacterial enzymes may be also related to the nutrient status. We propose that strong P-limitation (and low SRP) noted in subsystem II (Table 1) may have induced Crich PER. Under P-depleted conditions, phytoplankton releases large amounts of carbohydrates (Obernosterer and Herndl, 


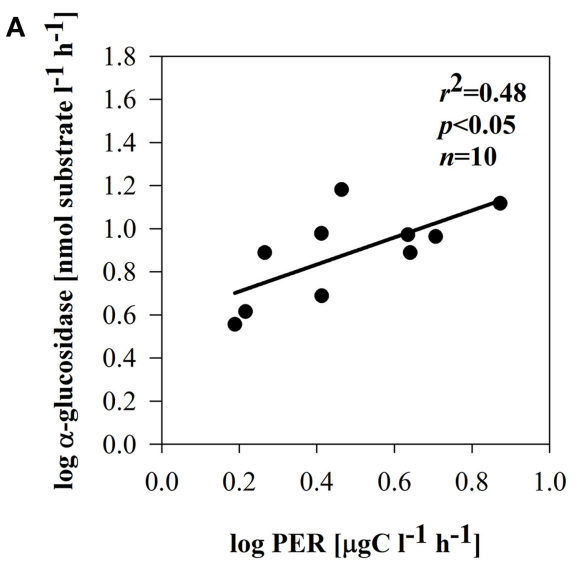

C

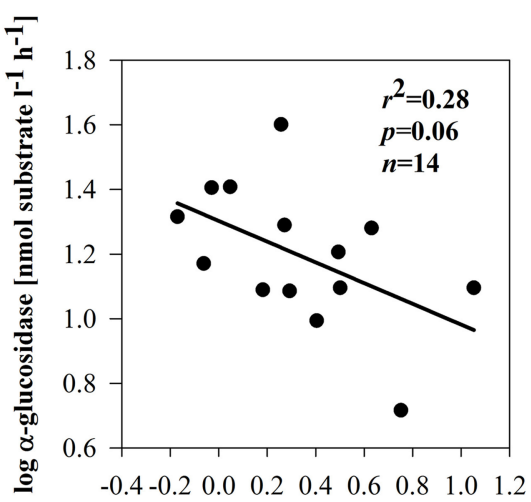

$\log$ PER $\left[\mu \mathrm{gC} \mathrm{I}^{-1} \mathrm{~h}^{-1}\right]$

E

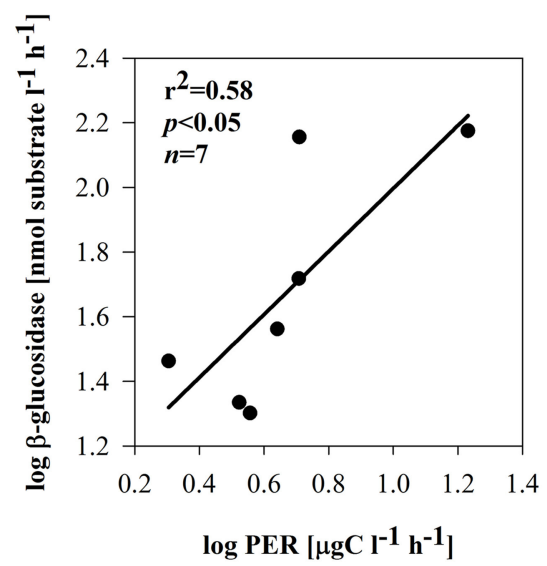

B

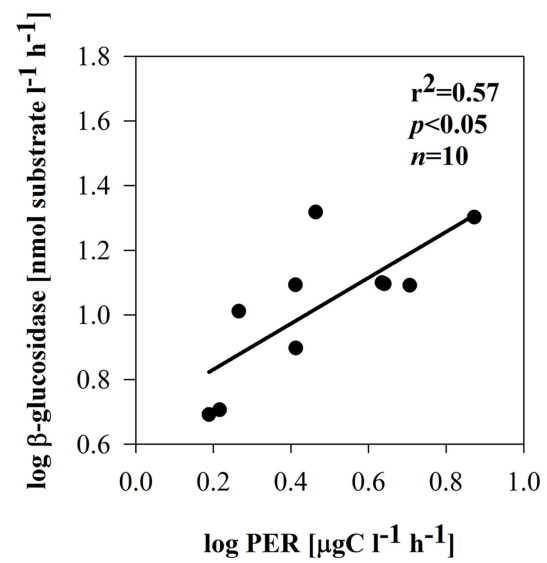

D

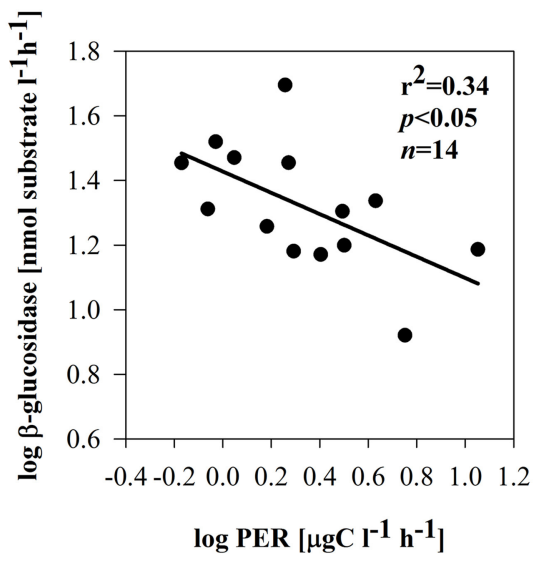

FIGURE 7 | Relationships between PER and $\alpha$-glucosidase and PER and $\beta$-glucosidase in subsystem I (A,B), subsystem II (C,D), and subsystem III (E). All data were log-transformed.

1995), which may have induced a high utilization of PER by bacteria. Utilizable PER implies a reduction of EEAb activity, and this could be responsible for the negative relation of glucosidases with PER (Figures 7C,D). A decrease of $\beta$-glucosidase produced by aquatic bacteria has been described as being linked to the introduction of phytoplankton-derived DOM (Chróst and Siuda, 2002). Furthermore, also in lake water the catabolic repression of glucosidases in the presence of easily assimilable substrates is described as an important mechanism controlling EEAb synthesis (Chróst, 1989).

However, in subsystem III nutrient limitation was unlikely, because DIN and SRP were high (Table 1). Other reasons (strong light limitation or viral lysis), potentially responsible for elevated PER here, need to be considered (compare Myklestad, 2000). In subsystem III (Table 1), a large portion of total primary production was exudated, reaching up to $50 \%$ (Figure 3B). The 
Table 4 | Multiple stepwise regressions between bacterial secondary production (BSP) and enzymatic activity (EEAa, EEAb, EEAleu, PhOx).

\begin{tabular}{|c|c|c|c|}
\hline & Independent variables & Regression equation & Adjusted $r^{2}$ \\
\hline Subsystem II BSP & PhOx $($ beta $=0.56 ; p<0.01)$ & $\log B S P=0.062+0.397 \log P h O x$ & 0.60 \\
\hline Subsystem III BSP & $\mathrm{EEAb}($ beta $=0.86 ; p<0.001)$ & $\log B S P=-0.469+0.797 \log E E A b$ & 0.72 \\
\hline
\end{tabular}

All data were log transformed. For abbreviations see text.

positive relation between PER and EEAb (Figure 7E) in subsystem III implies utilization of phytoplankton exudates that are mainly comprised of $\beta$-linked polysaccharides; these are often a predominant product of phytoplankton extracellular release (Biddanda and Benner, 1997) and from lysed cells (Weinbauer and Peduzzi, 1995). Although some of the primary production exudates contain quickly consumed compounds, actively growing phytoplankton also releases higher molecular weight organic matter, which is largely composed of polysaccharides (Lignell, 1990; Myklestad, 2000). We suggest that the quality of exudates triggered a greater activity of EEAb.

\section{WHAT SUPPORTS BACTERIAL PRODUCTION IN DISTINCT FLOODPLAIN SUBSYSTEMS?}

Based on our study, EEA appears to be a valuable tool for elucidating the potential linkage between non-chromophoric, but rapidly cycling DOM and bacterial production. Our results imply that in each of the three subsystems, the degradation of distinct material supported bacterial growth. The similar average BA and BSP rates in all subsystems (Figures 5A,B) - but significantly different EEA (Figures 4A-D), phytoplankton biomass and pPP rates (Figures 2A,B)-suggest that in each of the three subsystems, bacterial growth was supported by DOM from different sources. Typically, DOM of autochthonous origin is higher-quality material that mainly controls BSP (Cole et al., 2002), as opposed to allochthonously derived DOM, which is recalcitrant with much longer turnover times. These pools are produced independently from each other but both are available for bacteria (Del Giorgio and Pace, 2008). Although correlation between BSP and pPP has been demonstrated both in culture (Gurung et al., 1999) and field studies (Cole et al., 1988), our field data show that only in subsystem I was primary production (pPP) directly coupled to BSP or BA (see Results). At increased primary productivity bacteria can assimilate more phytoplankton-derived DOM (Piontek et al., 2012). Hence, we suggest that in subsystem I (with highest pPP noted), pPP derived-material supported bacterial production directly or by an enzyme-mediated step. Other studies from this area (Preiner et al., 2008) report stimulated phytoplankton productivity after floods in frequently connected water bodies. Also, according to the River Wave Concept (Humphries et al., 2014), autochthonous production of DOM predominates after floods. Hence, strong relation of pPP with EEAleu (Table 3) and of BSP with EEAleu (Table 4) implies that pPP products, hydrolyzed by EEAleu, supported BSP in I. Our results suggest that in frequently flooded river-floodplain systems (such as subsystem I), elevated bacterial growth could be driven mainly by enzymatic degradation of particulate primary production.
In subsystem II, a more refractory pool appears to also support bacterial growth. PhOx and EEAleu were the only enzymes that could explain any variability in BSP in II (Table 4). Positive relations of these enzymes with BSP here imply that organic matter degraded by PhOx and EEAleu could have become relatively more important as a source and promoted bacterial growth and abundance in subsystem II. Other studies in different environments support our findings. Lignin material led to increased bacterial abundance in soils where the bacterial population assimilated lignin-derived carbon (Deangelis et al., 2011). Also in peatlands bacterial growth was linked to phenol oxidase activity (Fenner et al., 2005). In freshwater, PhOx activity is less explored (Münster and De Haan, 1998) but bacteria seem to play a leading role in decomposing lignin in aquatic ecosystems ( $\mathrm{Li}$ et al., 2008). Lignin degradation is a relatively slow process (Benner and Kaiser, 2011) and significantly increases with higher temperature (Donnelly et al., 1990). Because lake water typically has a long residence time, such waters can be important places for microbial processing of carbon received from terrestrial sources. In river systems, occasional flood events are especially important in this process; they deliver significant amounts of low-age, terrestrial DOM (Berggren et al., 2009). We propose that semi-isolated floodplain side arms (such as subsystem II) provide opportunities for microbial processing of more refractory carbon. Sporadic inputs of fresh terrestrial material, reduced hydrodynamic stress due to rare flooding, high oxygen availability and the stimulating effect of phytoplankton on PhOx synthesis may create favorable conditions that could trigger the utilization of lignin-derived material.

Despite the elevated \% PER in subsystem III, no direct link between BSP and pPP or PER was observed. This could be because bacteria in that subsystem did not take up algaederived carbon directly. Our results, however, imply that BSP was driven by primary production here. This was found also in lakes with terrestrial input, where bacterial metabolism was driven by autochthonous primary production (Kritzberg et al., 2005). Even since mean pelagic primary production was significantly lower in III compared to the highly productive floodplain side arms of subsystem I, PER was still able to sustain bacterial metabolism also in subsystem III. In our study, close and positive relations of EEAb and BSP (Table 4) suggest that PER products, hydrolyzed by EEAb (Figure 7E), supported BSP. The activity of $\beta$-glucosidase is strongly stimulated by carbohydrates, which phytoplankton accumulates as a storage material (Mallet and Debroas, 2001; Børsheim et al., 2005). This may imply that $\beta$-linked polysaccharides derived from phytoplankton degradation could be beneficial sources sustaining bacterial growth in subsystem III. This allows 
us to suggest that in isolated floodplain lakes, despite high terrestrial input, bacterial growth can be also driven by autochthonous carbon sources to a certain extent (Robertson et al., 1999).

\section{EXTRACELLULAR ENZYMATIC ACTIVITY LINKING PRIMARY AND SECONDARY PRODUCTION}

Our results stress the importance of primary production in sustaining BSP in backwaters with a connectivity gradient. Nonetheless, the only modest variation of BSP compared to more dynamic primary production (pPP, PER, and chl $a$ ) demonstrates that organic matter derived from sources other than phytoplankton also supported BSP in this river-floodplain system. The potential coupling between bacterial and phytoplankton components can be indicated by the BSP:PPt ratio (Van Wambeke et al., 2002). This ratio is a measure for the importance of heterotrophic bacteria in consuming material from primary production (Kirchman, 2010). A high ratio could reflect significant input of terrestrial OM (Kirchman, 2012). The highest value in subsystem III implies that allochthonous, non-planktonic sources were relatively more important than bacterial utilization of phytoplankton-derived C (compare Tranvik, 1989; Gao et al., 2007). EEA measurements, however, point to phytoplankton exudates as an important source supporting BSP in subsystem III. Our study demonstrates that, despite the lack of data for a direct relationship between bacterial and phytoplankton components, the EEA analyses are able to elucidate the patterns relating these two variables, especially in systems with high terrestrial input.

Bacteria can utilize an increasing proportion of primary production, when phytoplankton is less efficient (Conan et al., 1999). At increased primary productivity, when phytoplankton is most active, the BSP:PPt ratio is the lowest (Almeida et al., 2005; Morana et al., 2014). The lowest ratio has been sometimes interpreted as a low flux of labile OM to bacteria (Ducklow et al., 2012), hence indicating a weak coupling between the bacterial and phytoplankton component. In our study, however, the lowest BSP:PPt ratio in subsystem I was accompanied by a strong coupling of BSP and pPP. Moreover, EEA measurements emphasize the significance of primary production (pPP, PER, and chl $a$ ) for bacterial utilization. Hence, we suggest that in subsystem I a fast transfer of phytoplankton-derived carbon to bacteria occurred: at elevated primary production, more of phytoplankton-derived material was assimilated by bacteria (compare De Kluijver et al., 2014). Our conclusion is that EEA measurements are very useful in describing the coupling of bacterial and phytoplankton components. The BSP:PPt ratio alone does not fully describe the strength of this link (Morán et al., 2002). Drawing conclusions based solely on that ratio simplifies the mechanisms that relate these two components (Almeida et al., 2005) potentially overlooking important links between bacteria and phytoplankton.

\section{ACKNOWLEDGMENTS}

Funding of this study was supported by the municipal water authority of Vienna (MA 45) and by the Austrian Science Fund (grants no. P17798 and P24604 to Peter Peduzzi). We are grateful to the National Park Authority and the Austrian River Authority for enabling our research in the Danube Floodplain National Park. We thank H. Kraill from the Department of
Limnology and Bio-Oceanography for chemical analyses and advice. We appreciate help and support of B. Goernet, M. Schabuss and H. Zornig. We also would like to thank three reviewers; their valuable comments improved the manuscript substantially.

\section{SUPPLEMENTARY MATERIAL}

The Supplementary Material for this article can be found online at: http://www.frontiersin.org/journal/10.3389/fmicb. 2015.00080/abstract

\section{REFERENCES}

Ågren, A., Buffam, I., Berggren, M., Bishop, K., Jansson, M., and Laudon, H. (2008). Dissolved organic carbon characteristics in boreal streams in a forest-wetland gradient during the transition between winter and summer. J. Geophys. Res. Biogeosci. (2005-2012) 113:G03031. doi: 10.1029/2007JG000674

Almeida, M., Cunha, M., and Alcântara, F. (2005). Relationship of bacterioplankton production with primary production and respiration in a shallow estuarine system (Ria de Aveiro, NW Portugal). Microbiol. Res. 160, 315-328. doi: 10.1016/j.micres.2005.02.005

Amon, R. M. W., and Benner, R. (1996). Bacterial utilization of different size classes of dissolved organic matter. Limnol. Oceanogr. 41, 41-51. doi: 10.4319/lo.1996.41.1.0041

Arnosti, C., Bell, C., Moorhead, D., Sinsabaugh, R., Steen, A., Stromberger, M., et al. (2014). Extracellular enzymes in terrestrial, freshwater, and marine environments: perspectives on system variability and common research needs. Biogeochemistry 117, 5-21. doi: 10.1007/s10533-013-9906-5

Baines, S. B., and Pace, M. L. (1991). The production of dissoved organic matter by phytoplankton and its importance to bacteria: patterns across marine and freshwater system. Limnol. Oceanogr. 36, 1078-1090. doi: 10.4319/lo.1991.36.6.1078

Barofsky, A., Vidoudez, C., and Pohnert, G. (2009). Metabolic profiling reveals growth stage variability in diatom exudates. Limnol. Oceanogr. Methods 7, 382-390. doi: 10.4319/lom.2009.7.382

Becker, J. W., Berube, P. M., Follett, C. L., Waterbury, J. B., Chisholm, S. W., Delong, E. F., et al. (2014). Closely related phytoplankton species produce similar suites of dissolved organic matter. Front. Microbiol. 5:111. doi: 10.3389/fmicb.2014.00111

Benner, R., and Kaiser, K. (2011). Biological and photochemical transformations of amino acids and lignin phenols in riverine dissolved organic matter. Biogeochemistry 102, 209-222. doi: 10.1007/s10533-010-9435-4

Benner, R., and Strom, M. (1993). A critical evaluation of the analytical blank associated with DOC measurements by high-temperature catalytic oxidation. Mar. Chem. 41, 153-160. doi: 10.1016/0304-4203(93)90113-3

Berger, B., Hoch, B., Kavka, G., and Herndl, G. J. (1995). Bacterial metabolism in the river Danube: parameters influencing bacterial production. Freshw. Biol. 34, 601-616. doi: 10.1111/j.1365-2427.1995.tb00916.x

Berggren, M., Laudon, H., and Jansson, M. (2009). Hydrological control of organic carbon support for bacterial growth in boreal headwater streams. Microb. Ecol. 57, 170-178. doi: 10.1007/s00248-008-9423-6

Bertilsson, S., and Jones, J. (2003). "Supply of dissolved organic matter to aquatic ecosystems: autochthonous sources," in Aquatic Ecosystems: Interactivity of Dissolved Organic Matter, eds S. Findlay and R. Sinsabaugh (San Diego, CA: Academic Press), 3-24.

Bianchi, T. S. (2012). The role of terrestrially derived organic carbon in the coastal ocean: a changing paradigm and the priming effect. Proc. Natl. Acad. Sci. U.S.A. 108, 19473-19481. doi: 10.1073/pnas.1017982108

Biddanda, B., and Benner, R. (1997). Carbon, nitrogen, and carbohydrate fluxes during the production of particulate and dissolved organic matter by marine phytoplankton. Limnol. Oceanogr. 42, 506-518. doi: 10.4319/lo.1997. 42.3.0506

Børsheim, K. Y., Vadstein, O., Myklestad, S. M., Reinertsen, H., Kirkvold, S., and Olsen, Y. (2005). Photosynthetic algal production, accumulation and release of phytoplankton storage carbohydrates and bacterial production in a gradient in daily nutrient supply. J. Plankton Res. 27, 743-755. doi: 10.1093/plankt/fbi047

Boschker, H., and Cappenberg, T. (1998). Patterns of extracellular enzyme activities in littoral sediments of Lake Gooimeer, The Netherlands. FEMS Microbiol. Ecol. 25, 79-86. doi: 10.1111/j.1574-6941.1998.tb00461.x 
Bunn, S. E., Davies, P. M., and Winning, M. (2003). Sources of organic carbon supporting the food web of an arid zone floodplain river. Freshw. Biol. 48, 619-635. doi: 10.1046/j.1365-2427.2003.01031.x

Chróst, R. (1989). Characterization and significance of b-glucosidase activity in lake water. Limnol. Oceanogr. 34, 660-672. doi: 10.4319/lo.1989.34.4.0660

Chróst, R. (1992). Significance of bacterial ectoenzymes in aquatic environments. Hydrobiologia 243/244, 61-70. doi: 10.1007/BF00007020

Chróst, R. J. (1991). "Environmental control of the synthesis and activity of aquatic microbial ectoenzymes," in Microbial Enzymes in Aquatic Environments, ed R. J. Chróst (New York, NY: Springer-Verlag), 29-59.

Chróst, R. J., and Siuda, W. (2002). "Ecology of microbial enzymes in lake ecosystems," in Enzymes in the Environment, eds R. G. Burns and R. P. Dick (New York, NY: Marcel Dekker, Inc), 35-72.

Chróst, R. J., and Siuda, W. (2006). Microbial production, utilization, and enzymatic degradation of organic matter in the upper trophogenic layer in the pelagial zone of lakes along a eutrophication gradient. Limnol. Oceanogr. 51, 749-762. doi: 10.4319/lo.2006.51.1_part_2.0749

Chrzanowski, T. H., and Hubbard, J. G. (1989). Bacterial utilization of algal extracellular products in a southwestern reservoir. Hydrobiologia 179, 61-71. doi: 10.1007/BF00011930

Cole, J. J. (1982). Interactions between bacteria and algae in aquatic ecosystems. Annu. Rev. Ecol. Syst. 13, 291-314. doi: 10.1146/annurev.es.13.110182. 001451

Cole, J. J., Carpenter, S. R., Kitchell, J. F., and Pace, M. L. (2002). Pathways of organic carbon utilization in small lakes: results from a whole-lake ${ }^{13} \mathrm{C}$ addition and coupled model. Limnol. Oceanogr. 47, 1664-1675. doi: 10.4319/lo.2002.47.6.1664

Cole, J. J., Findlay, S., and Pace, M. L. (1988). Bacterial production in fresh and saltwater ecosystems: a cross-system overview. Mar. Ecol. Prog. Ser. 43, 1-10. doi: 10.3354/meps043001

Conan, P., Turley, C., Stutt, E., Pujo-Pay, M., and Van Wambeke, F. (1999). Relationship between phytoplankton efficiency and the proportion of bacterial production to primary production in the Mediterranean Sea. Aquat. Microb. Ecol. 17, 131-144. doi: 10.3354/ame017131

Cunha, A., Almeida, A., Coelho, F., Gomes, N., Oliveira, V., and Santos, A. (2010). "Bacterial extracellular enzymatic activity in globally changing aquatic ecosystems" in Current Research, Technology and Education Topics in Applied Microbiology and Microbial Biotechnology, ed. A. Méndez-Vilas (Badajoz, Formatex Research Center), 124-135.

Deangelis, K. M., Allgaier, M., Chavarria, Y., Fortney, J. L., Hugenholtz, P., Simmons, B., et al. (2011). Characterization of trapped lignin-degrading microbes in tropical forest soil. PLoS ONE 6:e19306. doi: 10.1371/journal.pone.0019306

De Haan, H., and Boer, T. D. (1987). Applicability of light absorbance and fluorescence as measures of concentration and molecular size of dissolved organic carbon in humic lake Tjeukemeer. Wat. Res. 21, 731-734. doi: 10.1016/00431354(87)90086-8

De Kluijver, A., Schoon, P., Downing, J., Schouten, S., and Middelburg, J. (2014). Stable carbon isotope biogeochemistry of lakes along a trophic gradient. Biogeosci. Dis. 11, 6615-6646. doi: 10.5194/bgd-11-6615-2014

Del Giorgio, P. A., and Pace, M. L. (2008). Relative independence of dissolved organic carbon transport and processing in a large temperate river: the Hudson River as both pipe and reactor. Limnol. Oceanogr. 53, 185-197. doi: 10.4319/lo.2008.53.1.0185

Donnelly, P. K., Entry, J. A., Crawford, D. L., and Cromack, K. (1990). Cellulose and lignin degradation in forest soils: response to moisture, temperature, and acidity. Microb. Ecol. 20, 289-295. doi: 10.1007/BF02543884

Ducklow, H. W., and Carlson, C. A. (1992). "Oceanic bacterial production," in Advances in Microbial Ecology, ed. K. C. Marshall (New York, NY: Plenum Press), $113-181$.

Ducklow, H. W., Schofield, O., Vernet, M., Stammerjohn, S., and Erickson, M. (2012). Multiscale control of bacterial production by phytoplankton dynamics and sea ice along the western Antarctic Peninsula: a regional and decadal investigation. J. Mar. Syst. 98, 26-39. doi: 10.1016/j.jmarsys.2012. 03.003

Fajon, C., Cauwet, G., Lebaron, P., Terzic, S., Ahel, M., Malej, A., et al. (1999). The accumulation and release of polysaccharides by planktonic cells and the subsequent bacterial response during a controlled experiment. FEMS Microbiol. Ecol. 29, 351-363. doi: 10.1111/j.1574-6941.1999.tb00626.x
Fenner, N., Freeman, C., and Reynolds, B. (2005). Hydrological effects on the diversity of phenolic degrading bacteria in a peatland: implications for carbon cycling. Soil Biol. Biochem. 37, 1277-1287. doi: 10.1016/j.soilbio.2004. 11.024

Fogg, G. (1983). The ecological significance of extracellular products of phytoplankton photosynthesis. Bot. Mar. 26, 3-14. doi: 10.1515/botm.1983.26.1.3

Fouilland, E., and Mostajir, B. (2010). Revisited phytoplanktonic carbon dependency of heterotrophic bacteria in freshwaters, transitional, coastal and oceanic waters. FEMS Microbiol. Ecol. 73, 419-429. doi: 10.1111/j.15746941.2010.00896.x

Fuhrman, J. A., and Azam, F. (1982). Thymidine incorporation as a measure of heterotrophic bacterioplankton production in marine surface waters: evaluation and field results. Mar. Biol. 66, 109-120. doi: 10.1007/BF00397184

Gao, G., Qin, B., Sommaruga, R., and Psenner, R. (2007). The bacterioplankton of Lake Taihu, China: abundance, biomass, and production. Hydrobiologia 581, 177-188. doi: 10.1007/s10750-006-0511-7

Giroldo, D., and Vieira, A. A. H. (2005). Polymeric and free sugars released by three phytoplanktonic species from a freshwater tropical eutrophic reservoir. J. Plankton Res. 27, 695-705. doi: 10.1093/plankt/fbi043

Goto, N., Mitamura, O., and Terai, H. (2001). Biodegradation of photosynthetically produced extracellular organic carbon from intertidal benthic algae. J. Exp. Mar. Biol. Ecol. 257, 73-86. doi: 10.1016/S0022-0981(00)00329-4

Guenet, B., Danger, M., Abbadie, L., and Lacroix, G. (2010). Priming effect: bridging the gap between terrestrial and aquatic ecology. Ecology 91, 2850-2861. doi: 10.1890/09-1968.1

Gurung, T. B., Urabe, J., and Nakanishi, M. (1999). Regulation of the relationship between phytoplankton Scenedesmus acutus and heterotrophic bacteria by the balance of light and nutrients. Aquat. Microb. Ecol. 17, 27-35. doi: 10.3354/ame017027

Hein, T., Baranyi, C., Heiler, G., Holarek, C., Riedler, P., and Schiemer, F. (1999) Hydrology as a major factor determining plankton development in two floodplain segments and the River Danube, Austria. Large Rivers 11, 439-452. doi: $10.1127 / \mathrm{lr} / 11 / 1999 / 439$

Hein, T., Baranyi, C., Herndl, G. J., Wanek, W., and Schiemer, F. (2003). Allochthonous and autochthonous particulate organic matter in floodplains of the River Danube: the importance of hydrological connectivity. Freshw. Biol. 48, 220-232. doi: 10.1046/j.1365-2427.2003.00981.x

Hoostal, M. J., and Bouzat, J. L. (2008). The modulating role of dissolved organic matter on spatial patterns of microbial metabolism in Lake Erie sediments. Microb. Ecol. 55, 358-368. doi: 10.1007/s00248-007-9281-7

Hoppe, H. G. (1993). "Use of fluorogenic model substrates for extracellular enzyme activity (EEA) measurement of bacteria," in Methods in Aquatic Biology, eds P. Kemp, E. Sherr, and B. Sherr (Boca Raton, FL: Lewis), 423-431.

Hoppe, H.-G. (1983). Significance of exoenzymatic activities in the ecology of brackish water: measurements by means of methylumbelliferyL-substrates. Mar. Ecol. Prog. Ser. 11, 299-308. doi: 10.3354/meps011299

Hulatt, C. J., Thomas, D. N., Bowers, D. G., Norman, L., and Zhang, C. (2009). Exudation and decomposition of chromophoric dissolved organic matter (CDOM) from some temperate macroalgae. Estuar. Coast. Shelf Sci. 84, 147-153. doi: 10.1016/j.ecss.2009.06.014

Humphries, P., Keckeis, H., and Finlayson, B. (2014). The river wave concept: integrating river ecosystem models. BioSci. 64, 870-882. doi: 10.1093/biosci/biu130

Jaffé, R., McKnight, D., Maie, N., Cory, R., McDowell, W., and Campbell, J. (2008). Spatial and temporal variations in DOM composition in ecosystems: the importance of long-term monitoring of optical properties. J. Geophys. Res. Biogeosci. (2005-2012) 113: G04032. doi: 10.1029/2008JG000683

Jansson, M., Bergström, A.-K., Blomqvist, P., and Drakare, S. (2000). Allochthonous organic carbon and phytoplankton/bacterioplankton production relationships in lakes. Ecology 81, 3250-3255. doi: 10.1890/0012-9658(2000)081[3250:AOCAPB]2.0.CO;2

Jassby, A. D., and Platt, T. (1976). Mathematical formulation of the relationship between photosynthesis and light for the phytoplankton. Limnol. Oceanogr. 21, 540-547. doi: 10.4319/lo.1976.21.4.0540

Kirchman, D. L. (2010). Microbial Ecology of the Oceans. New York, NY: John Wiley \& Sons.

Kirchman, D. L. (2012). Processes in Microbial Ecology. Oxford, UK: Oxford University Press.

Kritzberg, E. S., Cole, J. J., Pace, M. L., Granéli, W., and Bade, D. L. (2004). Autochthonous versus allochthonous carbon sources of bacteria: results from 
whole-lake ${ }^{13} \mathrm{C}$ addition experiments. Limnol. Oceanogr. 49, 588-596. doi: 10.4319/lo.2004.49.2.0588

Kritzberg, E. S., Cole, J. J., Pace, M. M., and Granéli, W. (2005). Does autochthonous primary production drive variability in bacterial metabolism and growth efficiency in lakes dominated by terrestrial C inputs? Aquat. Microb. Ecol. 38, 103-111. doi: 10.3354/ame038103

Landa, M., Cottrell, M., Kirchman, D., Kaiser, K., Medeiros, P., Tremblay, L., et al. (2013). Phylogenetic and structural response of heterotrophic bacteria to dissolved organic matter of different chemical composition in a continuous culture study. Environ. Microbiol. 16, 1668-1681. doi: 10.1111/1462-2920.12242

Lennon, J. T., and Cottingham, K. L. (2008). Microbial productivity in variable resource environments. Ecology 89, 1001-1014. doi: 10.1890/07-1380.1

Li, J., Yuan, H., and Yang, J. (2008). Bacteria and lignin degradation. Front. Biol. China 4:8. doi: 10.1007/s11515-008-0097-8

Lignell, R. (1990). Excretion of organic carbon by phytoplankton: its relation to algal biomass, primary productivity and bacterial secondary productivity in the Baltic Sea. Mar. Ecol. Prog. Ser. 68, 85-99. doi: 10.3354/meps 068085

López-Sandoval, D. C., Marañón, E., Fernández, A., González, J., Gasol, J. M., Lekunberri, I., et al. (2010). Particulate and dissolved primary production by contrasting phytoplankton assemblages during mesocosm experiments in the Ría de Vigo (NW Spain). J. Plankton Res. 32, 1231-1240. doi: 10.1093/plankt/fbq045

López-Sandoval, D. C., Rodríguez-Ramos, T., Cermeño, P., and Marañón, E. (2013). Exudation of organic carbon by marine phytoplankton: dependence on taxon and cell size. Mar. Ecol. Prog. Ser. 477, 53-60. doi: 10.3354/meps10174

Lorenzen, C. J. (1967). Determination of chlorophyll and phaeopigments: spectrometric equations. Limnol. Oceanogr. 12, 343-346. doi: 10.4319/lo.1967.12.2.0343

Mallet, C., and Debroas, D. (2001). Regulation of $\beta$-and $\alpha$-glycolytic activities in the sediments of a eutrophic lake. Microb. Ecol. 41, 106-113. doi: $10.1007 / \mathrm{s} 002480000079$

Mason, H. S. (1948). The chemistry of melanin III. Mechanism of the oxidation of dihydroxyphenylalanine by tyrosinase. J. Biol. Chem. 172, 83-99.

McKnight, D. M. E. W., Boyer, P. K., Westerhoff, P. T., Doran, T., Kulbe, and Anderson, D. T. (2001). Spectroflourometric characterization of dissolved organic matter for indication of precursor organic material and aromaticity. Limnol. Oceanogr. 46, 38-48. doi: 10.4319/lo.2001.46.1.0038

Meon, B., and Kirchman, D. L. (2001). Dynamics and molecular composition of dissolved organic material during experimental phytoplankton blooms. Mar. Chem. 75, 185-199. doi: 10.1016/S0304-4203(01)00036-6

Morana, C., Sarmento, H., Descy, J.-P., Gasol, J. M., Borges, A., Bouillon, S., et al. (2014). Production of dissolved organic matter by phytoplankton and its uptake by heterotrophic prokaryotes in large tropical lakes. Limnol. Oceanogr. 59, 1364-1375. doi: 10.4319/lo.2014.59.4.1364

Morán, X., Estrada, M., Gasol, J., and Pedrós-Alió, C. (2002). Dissolved primary production and the strength of phytoplankton-bacterioplankton coupling in contrasting marine regions. Microb. Ecol. 44, 217-223. doi: 10.1007/s00248-002$1026-\mathrm{z}$

Münster, U., and De Haan, H. (1998). "The role of microbial extracellular enzymes in the transformation of dissolved organic matter in humic waters," in Aquatic Humic Substances, eds D. Hessen, and L. Tranvik (Berlin: Springer), 200-257.

Myklestad, S. (2000). "Dissolved organic carbon from phytoplankton," in Marine Chemistry, ed P. J. Wangersky (Berlin: Springer), 111-148. doi: 10.1007/10683826_5

Myklestad, S. M. (1995). Release of extracellular products by phytoplankton with special emphasis on polysaccharides. Sci. Total Environ. 165, 155-164. doi: 10.1016/0048-9697(95)04549-G

Norrman, B., Zweifel, U. L., Hopkinson C. S. Jr., and Fry, B. (1995). Production and utilization of dissolved organic carbon during an experimental diatom bloom. Limnol. Oceanogr. 40, 898-907. doi: 10.4319/lo.1995.40.5.0898

Obernosterer, I., and Herndl, G. J. (1995). Phytoplankton extracellular release and bacterial growth: dependence on the inorganic N: P ratio. Marine ecology progress series. Oldendorf 116, 247-257. doi: 10.3354/meps116247

Ogawa, H., Amagai, Y., Koike, I., Kaiser, K., and Benner, R. (2001). Production of refractory dissolved organic matter by bacteria. Science 292, 917-920. doi: 10.1126/science. 1057627

Parsons, T., Maita, Y., and Lalli, C. (1984). A Manual of Chemical and Biological Methods for Seawater Analysis. Oxford: Pergamon Press.
Pausz, C., and Herndl, G. J. (1999). Role of ultraviolet radiation on phytoplankton extracellular release and its subsequent utilization by marine bacterioplankton. Aquat. Microb. Ecol. 18, 85-93. doi: 10.3354/ame018085

Peduzzi, P., Aspetsberger, F., Hein, T., Huber, F., KargL-Wagner, S., Luef, B., et al. (2008). Dissolved organic matter (DOM) and bacterial growth in floodplains of the Danube River under varying hydrological connectivity. Fund. Appl. Limnol. 171, 49-61. doi: 10.1127/1863-9135/2008/0171-0049

Penna, A., Berluti, S., Penna, N., and Magnani, M. (1999). Influence of nutrient ratios on the in vitro extracellular polysaccharide production by marine diatoms from the Adriatic Sea. J. Plankton Res. 21, 1681-1690. doi: 10.1093/plankt/21.9.1681

Peterson, B. J. (1980). Aquatic primary productivity and the $14 \mathrm{C}-\mathrm{CO}_{2}$ method: a history of the productivity problem. Annu. Rev. Ecol. Syst. 359-385. doi: 10.1146/annurev.es.11.110180.002043

Pind, A., Freeman, C., and Lock, M. (1994). Enzymic degradation of phenolic materials in peatlands-measurement of phenol oxidase activity. Plant Soil 159, 227-231. doi: 10.1007/BF00009285

Piontek, J., Borchard, C., Sperling, M., Schulz, K. G., Riebesell, U., and Engel, A. (2012). Response of bacterioplankton activity in an Arctic fjord system to elevated pCO 2: results from a mesocosm perturbation study. Biogeosci. Dis. 9, 10467-10511. doi: 10.5194/bgd-9-10467-2012

Porter, K. G., and Feig, Y. S. (1980). The use of DAPI for identifying and counting aquatic microflora. Limnol. Oceanogr. 25, 943-948. doi: 10.4319/lo.1980.25.5.0943

Preiner, S., Drozdowski, I., Schagerl, M., Schiemer, F., and Hein, T. (2008). The significance of side-arm connectivity for carbon dynamics of the River Danube, Austria. Freshw. Biol. 53, 238-252. doi: 10.1111/j.1365-2427.2007.01888.x

Riedler, P., and Schagerl, M. (1998). Pelagic primary production and related parameters in the River Danube near Vienna (Austria). Large Rivers 11, 139-151.

Rier, S. T., Kuehn, K. A., and Francoeur, S. N. (2007). Algal regulation of extracellular enzyme activity in stream microbial communities associated with inert substrata and detritus. J. Inf. 26, 439-449. doi: 10.1899/06-080.1

Rier, S. T., Shirvinski, J. M., and Kinek, K. C. (2014). In situ light and phosphorus manipulations reveal potential role of biofilm algae in enhancing enzyme-mediated decomposition of organic matter in streams. Freshw. Biol. 59, 1039-1051. doi: 10.1111/fwb.12327

Robertson, A., Bunn, S., Walker, K., and Boon, P. (1999). Sources, sinks and transformations of organic carbon in Australian floodplain rivers. Mar. Freshw. Res. 50, 813-829. doi: 10.1071/MF99112

Rochelle-Newall, E., and Fisher, T. (2002). Production of chromophoric dissolved organic matter fluorescence in marine and estuarine environments: an investigation into the role of phytoplankton. Mar. Chem. 77, 7-21. doi: $10.1016 /$ S0304-4203(01)00072-X

Romera-Castillo, C., Sarmento, H., Álvarez-Salgado, X. A., Gasol, J. M., and Marrasé, C. (2011). Net production and consumption of fluorescent colored dissolved organic matter by natural bacterial assemblages growing on marine phytoplankton exudates. Appl. Environ. Microbiol. 77, 7490-7498. doi: 10.1128/AEM.00200-11

Sarmento, H., and Gasol, J. M. (2012). Use of phytoplankton-derived dissolved organic carbon by different types of bacterioplankton. Environ. Microbiol. 14, 2348-2360. doi: 10.1111/j.1462-2920.2012.02787.x

Schagerl, M., Krbec, H., Nairz, S., and Wieltschnig, C. (1996). Pelagische Primärproduktion in einem Donaualtarm bei Regelsbrunn (Niederösterreich). Verh. Zool. Bot. Ges. Österreich 133, 201-216.

Schiemer, F., Baumgartner, C., and Tockner, K. (1999). The Danube restoration project: conceptual framework, monitoring program and predictions on hydrologically controlled changes. Reg. Rivers Res. Manage. 15, 231-244.

Shimp, R. J., and Pfaender, F. K. (1985). Influence of easily degradable naturally occurring carbon substrates on biodegradation of monosubstituted phenols by aquatic bacteria. Appl. Environ. Microbiol. 49, 394-401.

Sieczko, A., and Peduzzi, P. (2014). Origin, enzymatic response and fate of dissolved organic matter during flood and non-flood conditions in a river-floodplain system of the Danube (Austria). Aquat. Sci. 76, 115-129. doi: 10.1007/s00027013-0318-3

Sinsabaugh, R. L. (2010). Phenol oxidase, peroxidase and organic matter dynamics of soil. Soil Biol. Biochem. 42, 391-404. doi: 10.1016/j.soilbio.2009.10.014

Sinsabaugh, R. L., and Follstad Shah, J. J. (2012). Ecoenzymatic stoichiometry and ecological theory. Ann. Rev. Ecol. Evol. Syst. 43, 313-343. doi: 10.1146/annurevecolsys-071112-124414 
Sinsabaugh, R. L., and Foreman, C. M. (2001). Activity profiles of bacterioplankton in an eutrophic river. Freshw. Biol. 46, 1239-1249. doi: 10.1046/j.13652427.2001.00748.x

Stedmon, C. A., and Markager, S. (2005). Tracing the production and degradation of autochthonous fractions of dissolved organic matter by fluorescence analysis. Limnol. Oceanogr. 50:1415. doi: 10.4319/lo.2005.50.5.1415

Steemann-Nielsen, E. (1974). "Light and primary production," in Optical Aspects of Oceanography, eds N. G. Jerlov and E. Steemann-Nielsen (London: Academic Press), 361-388.

Teira, E., Pazó, M. J., Quevedo, M., Fuentes, M., Niell, F., and Fernández, E. (2003). Rates of dissolved organic carbon production and bacterial activity in the eastern North Atlantic Subtropical Gyre during summer. Mar. Ecol. Prog. Ser. 249, 53-67. doi: 10.3354/meps249053

Thorp, J. H., and Delong, D. (2002). Dominance of autochthonous autotrophic carbon in food webs of heterotrophic rivers. Oikos 96, 543-550. doi: 10.1034/j.1600-0706.2002.960315.x

Tranvik, L. J. (1989). Bacterioplankton growth, grazing mortality and quantitative relationship to primary production in a humic and a clearwater lake. J. Plankton Res. 11, 985-1000. doi: 10.1093/plankt/11.5.985

Treignier, C., Derenne, S., and Saliot, A. (2006). Terrestrial and marine $\mathrm{n}$-alcohol inputs and degradation processes relating to a sudden turbidity current in the Zaire canyon. Org. Geochem. 37, 1170-1184. doi: 10.1016/j.orggeochem.2006.03.010

Van Wambeke, F., Heussner, S., Diaz, F., Raimbault, P., and Conan, P. (2002). Small-scale variability in the coupling/uncoupling of bacteria, phytoplankton and organic carbon fluxes along the continental margin of the Gulf of Lions, Northwestern Mediterranean Sea. J. Mar. Syst. 33, 411-429. doi: 10.1016/S09247963(02)00069-6

Wagner, K., Bengtsson, M. M., Besemer, K., Sieczko, A., Burns, N. R., Herberg, E. R., et al. (2014). Functional and structural responses of hyporheic biofilms to varying sources of dissolved organic matter. Appl. Environ. Microbiol. 80, 6004-6012. doi: 10.1128/AEM.01128-14

Weinbauer, M. G., and Peduzzi, P. (1995). Effect of virus-rich high molecular weight concentrates of seawater on the dynamics of dissolved amino acids and carbohydrates. Mar. Ecol. Prog. Ser. 127, 245-253. doi: 10.3354/meps 127245
Weishaar, J. L., Aiken, G. R., Bergamaschi, B. A., Fram, M. S., Fujii, R., and Mopper, K. (2003). Evaluation of specific ultraviolet absorbance as an indicator of the chemical composition and reactivity of dissolved organic carbon. Environ. Sci. Technol. 37, 4702-4708. doi: 10.1021/es030360x

Wetzel, R. G., and Linkens, G. E. (1990). Limnolgical Analyses. Berlin: Springer.

Wilczek, S., Fischer, H., and Pusch, M. T. (2005). Regulation and seasonal dynamics of extracellular enzyme activities in the sediments of a large lowland river. Microb. Ecol. 50, 253-267. doi: 10.1007/s00248-004-0119-2

Wyatt, K. H., Tellez, E., Woodke, R. L., Bidner, R. J., and Davison, I. R. (2014). Effects of nutrient limitation on the release and use of dissolved organic carbon from benthic algae in Lake Michigan. Freshw. Sci. 33, 557-567. doi: $10.1086 / 675453$

Young, K. C., Docherty, K. M., Maurice, P. A., and Bridgham, S. D. (2005). Degradation of surface-water dissolved organic matter: influences of DOM chemical characteristics and microbial populations. Hydrobiologia 539, 1-11. doi: 10.1007/s10750-004-3079-0

Conflict of Interest Statement: The authors declare that the research was conducted in the absence of any commercial or financial relationships that could be construed as a potential conflict of interest.

Received: 22 October 2014; accepted: 22 January 2015; published online: 17 February 2015.

Citation: Sieczko A, Maschek M and Peduzzi P (2015) Algal extracellular release in river-floodplain dissolved organic matter: response of extracellular enzymatic activity during a post-flood period. Front. Microbiol. 6:80. doi: 10.3389/fmicb.2015.00080

This article was submitted to Aquatic Microbiology, a section of the journal Frontiers in Microbiology.

Copyright (c) 2015 Sieczko, Maschek and Peduzzi. This is an open-access article distributed under the terms of the Creative Commons Attribution License (CC BY). The use, distribution or reproduction in other forums is permitted, provided the original author(s) or licensor are credited and that the original publication in this journal is cited, in accordance with accepted academic practice. No use, distribution or reproduction is permitted which does not comply with these terms. 